EECENED

SEP 03980

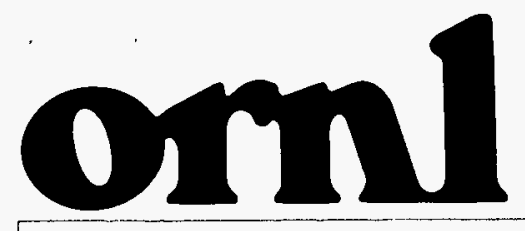

OAK RIDGE NATIONAL LABORATORY

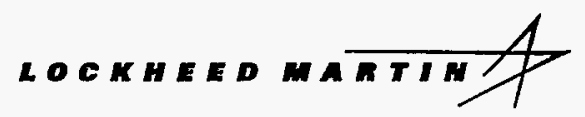

MANAGED AND OPERATED BY LOCKHEED MARTIN ENERGY RESEARCH CORPORATION FOR THE UNTED STATES DEPARTMENT OF ENERGY

ORNL-27 (3-96)

OSTI

ORNL/TM-13224

Radiological Dose Assessment

of Department of Energy Pinellas Plant

Waste

Proposed for Disposal at

Laidlaw Environmental Services of South Carolina, Inc.

\author{
M. L. Socolof \\ D. W. Lee
}

Energy Division

Oak Ridge National Laboratory

Oak Ridge, Tennessee 37831

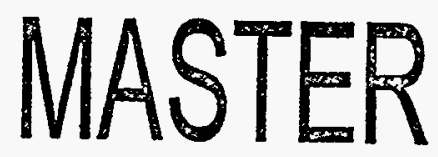


This report has been reproduced directly from the best available copy.

Available to DOE and DOE contractors from the Office of Scientific and Technical Information, P.O. Box 62, Oak Ridge, TN 37831; prices available from (615) 576-8401, FTS 626-8401.

Available to the public from the National Technical Information Service, U.S. Department of Commerce, 4284 Port Royal Rd., Springfield, VA 22161.

This report was prepared as an account of work sponsored by an agency of United States Government. Neither the United States Government nor any agency thereof, nor any of their employees, makes any warranty. express or implied, or assumes any legal liability or responsibility for the accuracy, completeness, or usefulness of any information, apparatus, product, or process disclosed, or represents that its use would not infringe privately owned rights. Reference herein to any specific commercial product, process, or service by trade name, trademark, manufacturer, or otherwise, does not necessarily constitute or imply its endorsement, recommendation, or favoring by the United States Government or any agency thereof. The views and opinions of authors expressed herein do not necessarily state or reflect those of the United States Government or any agency thereof. 


\title{
Radiological Dose Assessment \\ of Department of Energy Pinellas Plant Waste \\ Proposed for Disposal at \\ Laidlaw Environmental Services of South Carolina, Inc.
}

\author{
M. L. Socolof \\ D. W. Lee
}

\begin{abstract}
Energy Division
Oak Ridge National Laboratory

Oak Ridge, Tennessee 37831
\end{abstract}

May 1996

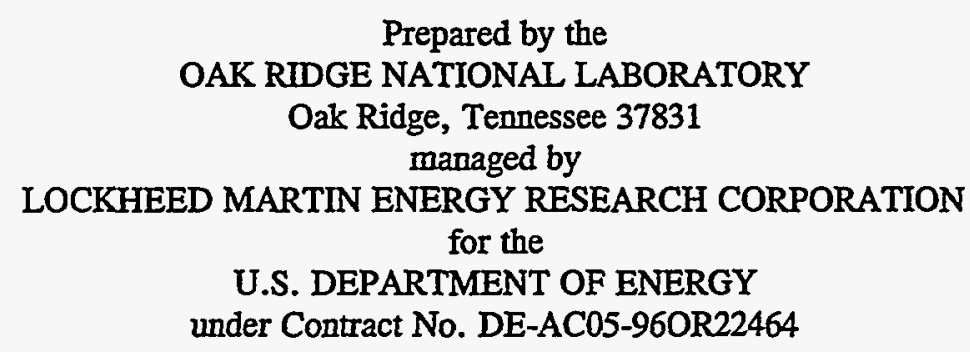




\section{DISCLAIMER}

Portions of this document may be illegible in electronic image products. Images are produced from the best available original document. 


\section{TABLE OF CONTENTS}

ABSTRACT $\ldots \ldots \ldots \ldots \ldots \ldots \ldots \ldots \ldots \ldots \ldots \ldots \ldots \ldots \ldots \ldots \ldots \ldots$ ix TABLE OF CONTENTS $\ldots \ldots \ldots \ldots \ldots \ldots \ldots \ldots \ldots \ldots \ldots \ldots \ldots \ldots \ldots$ iii LIST OF TABLES AND FIGURES $\ldots \ldots \ldots \ldots \ldots \ldots \ldots \ldots \ldots \ldots, \ldots$ LIST OF ABBREVIATIONS AND ACRONYMS $\ldots \ldots \ldots \ldots \ldots \ldots \ldots \ldots$ vii

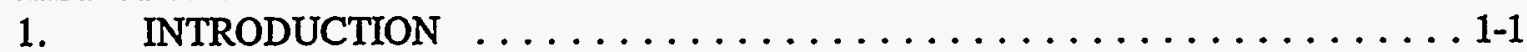

2. FACILITY DESCRIPTION AND OPERATIONS $\ldots \ldots \ldots \ldots \ldots \ldots \ldots 2-1$

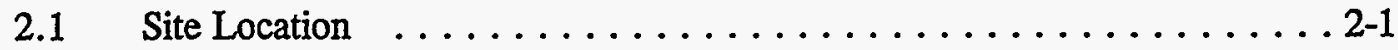

2.2 Facility Description . . . . . . . . . . . . . . .

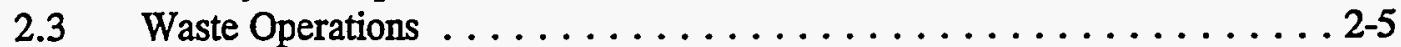

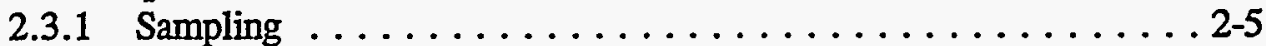

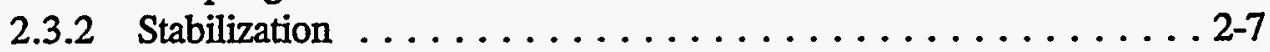

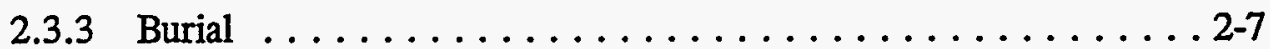

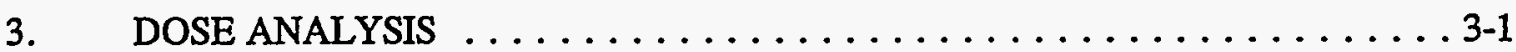

3.1 Worker Exposure Scenarios $\ldots \ldots \ldots \ldots \ldots \ldots \ldots \ldots \ldots \ldots \ldots \ldots \ldots \ldots \ldots$

3.1.1 Sampling $\ldots \ldots \ldots \ldots \ldots \ldots \ldots \ldots \ldots \ldots \ldots \ldots \ldots \ldots \ldots \ldots \ldots \ldots, 3$



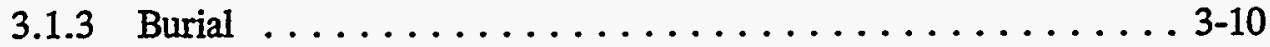

3.1.3.1 Acute exposure $\ldots \ldots \ldots \ldots \ldots \ldots .3-10$

3.1.3.2 Chronic exposure ............... 3-11

3.2 Public Exposure Scenario $\ldots \ldots \ldots \ldots \ldots \ldots \ldots \ldots \ldots \ldots \ldots \ldots \ldots \ldots \ldots$

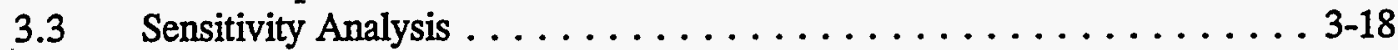

3.3.1 Worker exposure scenarios $\ldots \ldots \ldots \ldots \ldots \ldots \ldots \ldots .3-18$

3.3.2 Public exposure scenario $\ldots \ldots \ldots \ldots \ldots \ldots \ldots \ldots \ldots \ldots \ldots \ldots, 22$

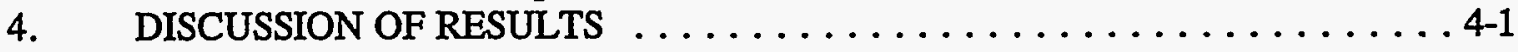

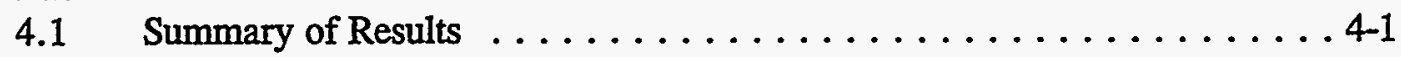

4.2 Comparison to Background and Regulatory Limits $\ldots \ldots \ldots \ldots \ldots$ 4-1

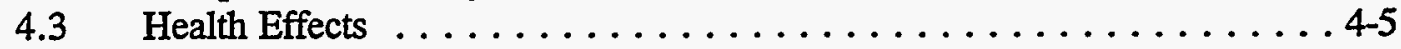

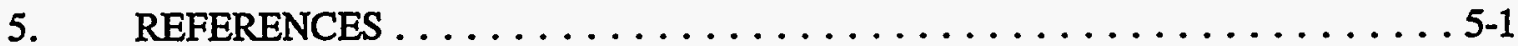

APPENDIX A - RESRAD, Version 5.60, Input Parameter and Dose Summary ...... A-1 



\section{LIST OF TABLES}

3.1 Parameter values for worker exposure sensitivity analysis $\ldots \ldots \ldots \ldots \ldots$ 3-20

3.2 Sensitivity analysis for worker exposure calculations . . . . . . . . . 3-20

3.3 Summary of RESRAD sensitivity analysis for public exposure calculation . . . 3-25

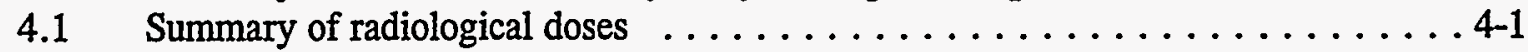

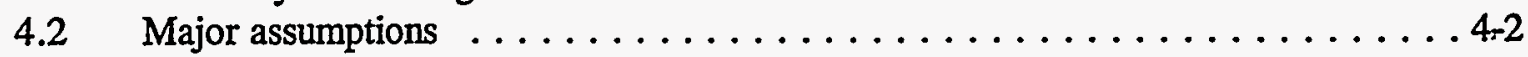

\section{LIST OF FIGURES}

2.1 Laidlaw Facility Location, Pinewood, South Carolina . . . . . . . . . . . . 2-2

2.2 Laidlaw Facility Plan . . . . . . . . . . . . . . . . . . . 2-4

2.3 Cross-section of Laidlaw Liner Systems . . . . . . . . . . . . . . . . 2-6

3.1 Public Dose from Ingestion of Tritium-contaminated Drinking Water . . . . . 3-19 



\section{LIST OF ABBREVIATIONS AND ACRONYMS}

DCF dose conversion factor

DOE U.S. Department of Energy

EPA U.S. Environmental Protection Agency

HDPE high-density polyethylene

LCRS Leachate Collection and Removal System

LDCRS Leachate Detection, Collection, and Removal System

RCRA Resource Conservation and Recovery Act

RESRAD RESRAD computer code, Version 5.60

\section{LIST OF UNITS}

$\begin{array}{ll}{ }^{\circ} \mathrm{C} & \text { degrees Celsius } \\ \mathrm{Ci} & \text { curie } \\ \mathrm{cm} & \text { centimeter } \\ \mathrm{ft} & \text { foot/feet } \\ { }^{\circ} \mathrm{F} & \text { degrees Fahrenheit } \\ \mathrm{g} & \text { gram } \\ \mathrm{in} . & \text { inches } \\ \mathrm{K} & \text { kelvin } \\ \mathrm{km} & \text { kilometer } \\ \mathrm{m} & \text { meter } \\ \mathrm{mm} \mathrm{Hg} & \text { millimeters of mercury } \\ \mathrm{mol} & \text { mole } \\ \mathrm{mph} & \text { miles per hour } \\ \mathrm{mrem} & \text { millirem } \\ \mathrm{mSv} & \text { milliSievert } \\ \mathrm{s} & \text { second } \\ \mathrm{y} & \text { year }\end{array}$




\begin{abstract}
The U.S. Department of Energy (DOE) Pinellas Plant in Largo, FL is proposing to ship and dispose of hazardous sludge, listed as F006 waste, to the Laidlaw Environmental Services of South Carolina, Inc. (Laidlaw) treatment, storage, and disposal facility in Pinewood, South Carolina. This sludge contains radioactive tritium in concentrations of about $28 \mathrm{pCi} / \mathrm{g}$. The objective of this study is to assess the possible radiological impact to workers at the Laidlaw facility and members of the public due to the handling, processing, and burial of the DOE waste containing tritium. Listed below are the estimated doses to workers from waste handling activities and to the public from disposed waste. These estimated doses are compared to natural background and applicable regulatory limits. The results of this highly conservative dose assessment reveal low annual doses that are far below natural background radiation exposure and regulatory limits. Note that the estimated doses are incremental doses above background or other sources of radiation exposure.
\end{abstract}

\title{
Summary of radiological doses
}

\begin{tabular}{|c|c|c|c|}
\hline Exposure scenario & Dose $(\mathrm{mrem} / \mathrm{y})^{a}$ & $\begin{array}{l}\text { fraction of natural } \\
\text { background }^{b}\end{array}$ & $\begin{array}{c}\text { fraction of regulatory } \\
\text { limit }^{c}\end{array}$ \\
\hline Waste sampling & $7.2 \times 10^{-6}$ & $2.4 \times 10^{-8}$ & $1.4 \times 10^{-9}$ \\
\hline Waste stabilization & $2.4 \times 10^{-6}$ & $8.0 \times 10^{-9}$ & $4.8 \times 10^{-10}$ \\
\hline \multicolumn{4}{|l|}{ Waste burial } \\
\hline acute & $9.9 \times 10^{-7}$ & $3.3 \times 10^{-9}$ & $2.0 \times 10^{-10}$ \\
\hline chronic & $1.5 \times 10^{-6}$ & $5.0 \times 10^{-9}$ & $3.0 \times 10^{-10}$ \\
\hline Public exposure ${ }^{d}$ & $5.7 \times 10^{-1}$ & $1.9 \times 10^{-3}$ & $5.7 \times 10^{-3}$ \\
\hline \multicolumn{4}{|c|}{$\begin{array}{l}\text { Waste sampling, waste stabilization, and acute burial doses are from short-term exposure scenarios that } \\
\text { hin one year. Because the doses are so low, no acute radiation effects are anticipated. Therefore, the most } \\
\text { le comparison is to annual background and annual occupational dose levels. The chronic waste burial and } \\
\text { posure scenarios are from longer-term exposures that are also compared to annual background and annual } \\
\text { nal doses. } \\
b \text { Annual average individual natural background level is } 300 \mathrm{mrem} \text {. } \\
\text { Cocupational limit }=5000 \mathrm{mrem} / \mathrm{y} ; \text { public limit }=100 \mathrm{mrem} / \mathrm{y} \text {. } \\
{ }^{a} \text { Peak annual exposure occurs about } 2 \text { years after placement of waste. }\end{array}$} \\
\hline
\end{tabular}




\section{INTRODUCTION}

The U.S. Department of Energy (DOE) Pinellas Plant in Largo, FL (Pinellas) is proposing to ship and dispose of hazardous sludge to the Laidlaw Environmental Services of South Carolina, Inc. (Laidlaw) treatment, storage, and disposal facility in Pinewood, South Carolina. This sludge, listed under the Resource Conservation and Recovery Act (RCRA) regulations as F006 waste, contains radioactive tritium. RCRA F006 waste is defined as wastewater treatment sludges from electroplating operations [40 Code of Federal Regulations Part 261.30]. Because the waste contains tritium, DOE requires the preparation of a radiological dose assessment prior to shipment and disposal to ensure the protection of workers and the public from radiation hazards. A radiological dose assessment is necessary to meet the requirements of DOE to allow for an exemption from the department's moratorium on the offsite shipment of radioactively contaminated wastes. This assessment is modeled after a similar one conducted for Pinellas sludge that was sent to the Laidlaw facility in 1992 (M. H. Chew \& Associates 1994).

The objective of this study is to assess an upper-bound radiological impact to workers at the Laidlaw facility and to members of the public due to the handling, processing, and burial of the DOE waste containing tritium. Beta particle radiation (i.e., electrons resulting from the conversion of a neutron to a proton in the nucleus of an atom) from the tritium could result in radiation exposure to workers or members of the public. The potential off-site public dose is calculated as an upper bound for the hypothetical maximally exposed off-site individual. The study also compares the calculated doses with background radiation levels and applicable federal regulatory limits. Finally, associated health effects are discussed.

The remainder of this report is organized into three sections: (1) a description of the disposal facility and operations; (2) the dose analysis, including the methodology for calculating doses to workers and the public, and a sensitivity analysis; and (3) a discussion of the results. 


\section{FACILITY DESCRIPTION AND OPERATIONS}

\subsection{SITE LOCATION}

The Laidlaw treatment, storage, and disposal facility is located near Pinewood, South Carolina (Fig. 2.1). The facility is approximately $9.7 \mathrm{~km}$ (6 miles) south of the City of Pinewood, which has a population of about 600 people (1990 census) and approximately $32 \mathrm{~km}$ (20 miles) southwest of the City of Sumter, which has a population of about 42,000 people (1990 census). The nearest off-site resident is approximately $300 \mathrm{~m}$ (1,000 ft) east of the Laidlaw facility boundary. According to the Laidlaw Environmental Services Informational Audit Package (no date; received from Todd Blake, Laidlaw Environmental Services of South Carolina, Inc. March 11, 1996), the estimated population within $4.8 \mathrm{~km}$ ( 3 miles) of the facility is 100 people. The predominant land use within $4.8 \mathrm{~km}$ ( 3 miles) is agricultural. Remaining areas are in various successional stages of woodland.

Columbia, South Carolina, which is the nearest city for which National Weather Service Data are available, is approximately $56 \mathrm{~km}$ ( 35 miles) northwest of the facility. The climate is warm and humid with an average annual rainfall of approximately $127 \mathrm{~cm}(50 \mathrm{in}$.) in Columbia (DOC 1995). The annual average of the normal daily mean temperature is $17.3^{\circ} \mathrm{C}$ $\left(63.1^{\circ} \mathrm{F}\right)$. The mean daily high temperature in the hottest month (July) is $33.1^{\circ} \mathrm{C}\left(91.6^{\circ} \mathrm{F}\right)$. The transfer of the Pinellas sludge to Laidlaw is expected to occur in April or May. In April, the average daily maximum temperature in Columbia is $24.7^{\circ} \mathrm{C}\left(76.5^{\circ} \mathrm{F}\right)$ and in May is $28.6^{\circ} \mathrm{C}$ $\left(83.5^{\circ} \mathrm{F}\right)$ (DOC 1995). The annual average wind speed in Columbia, South Carolina is approximately $3 \mathrm{~m} / \mathrm{s}$ (6.7 mph) (DOC 1995).

The uppermost groundwater is used for local private residences and light industrial activities. The depth to the usable water table aquifer (i.e., thickness of the unsaturated zone)

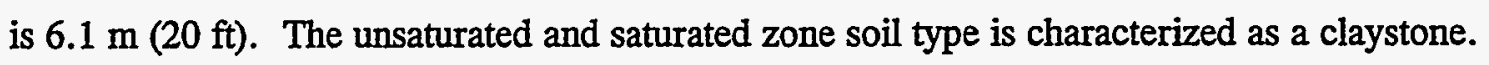
The hydraulic conductivity of the unsaturated soil is between $10^{-3}$ and $10^{-5} \mathrm{~cm} / \mathrm{s}$, and of the confining layers above the usable aquifer is between $10^{-4}$ and $10^{-7} \mathrm{~cm} / \mathrm{s}$ (Laidlaw Environmental Services Informational Audit Package, no date; received from Todd Blake, Laidlaw Environmental Services of South Carolina, Inc. March 11, 1996). The hydraulic conductivity of the usable water table aquifer ranges from $1.06 \times 10^{-2}$ to $7.87 \times 10^{-5} \mathrm{~cm} / \mathrm{s}[\mathrm{M}$. Walker, Laidlaw Environmental Services of South Carolina, Inc., personal communication with M. L. Socolof, Oak Ridge National Laboratory (ORNL), March 27, 1996]. There are no drinking water wells located downgradient of the facility. The nearest well is an on-site production/potable water well withdrawing water from the Black Creek aquifer. Groundwater 

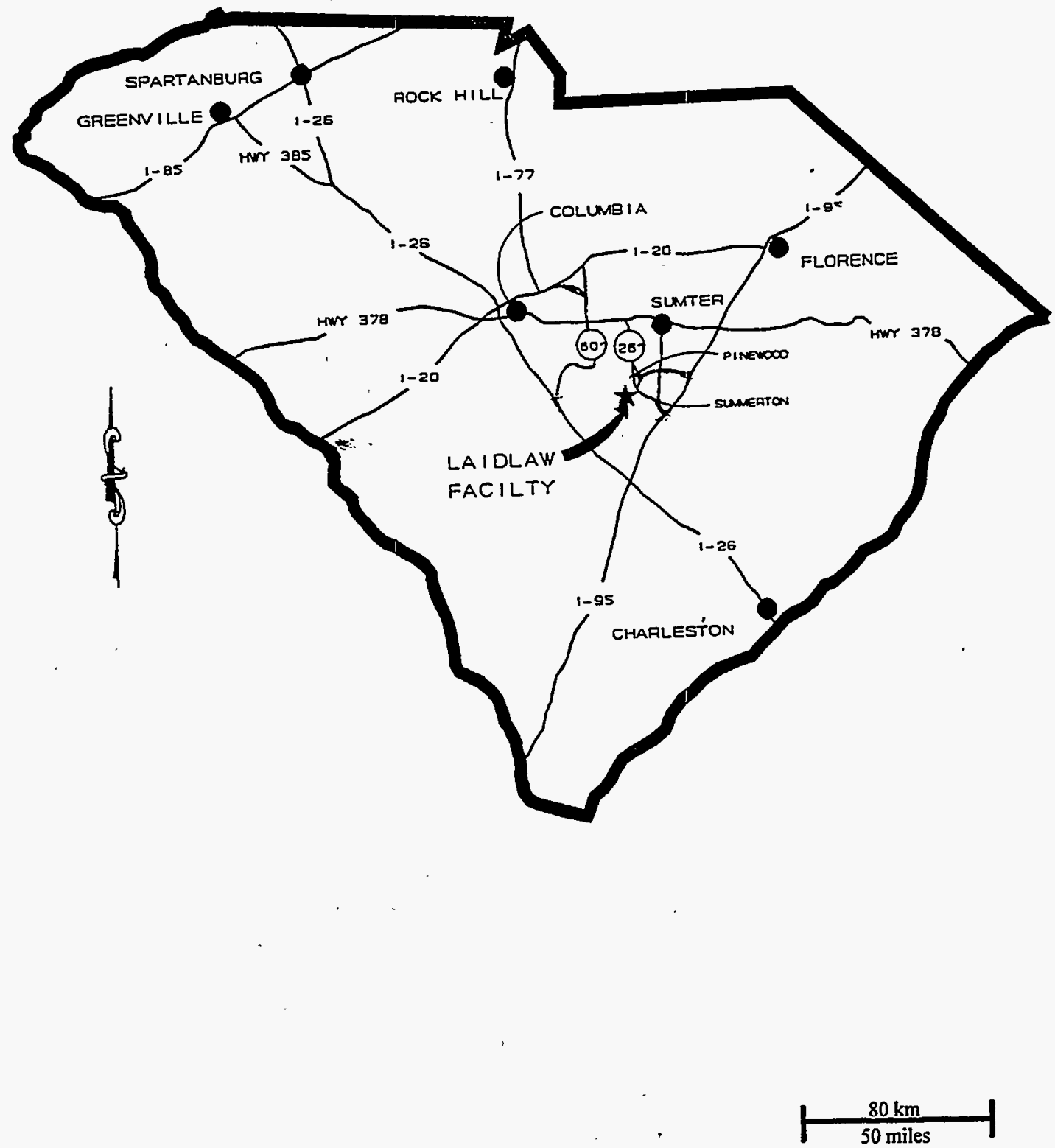

Fig. 2.1. Laidlaw Facility Location, Pinewood, South Carolina. 
provides water for the surrounding population [i.e., 100 people in the surrounding $4.8 \mathrm{~km}$ ( 3 miles)]. Surface waters within $4.8 \mathrm{~km}$ ( 3 miles) include Lake Marion and various sized ponds. Lake Marion is located at the property boundary. Area surface waters are available for industrial and commercial supplies, power generation, agriculture, and drinking water supplies. While Lake Marion has the potential to serve as a water supply, it is presently not being used for one (Laidlaw Environmental Services of South Carolina Informational Audit Package, no date, per Todd Blake, Laidlaw Environmental Services of South Carolina, received March 11, 1996). Lake Marion is also used for fishing and swimming.

\section{$2.2 \quad$ Facility Description}

The Laidlaw facility consists of $113 \mathrm{ha}$ ( 279 acres) and is permitted to stabilize and bury waste in its on-site landfill. The facility is operating under a RCRA permit and processes liquids, sludge, solid wastes in drums, bulk contaminated soil, refinery waste, wastewater treatment sludge, brine solids, plating waste, site and spill cleanup waste, and ash from incinerators. Laidlaw has the capacity to conduct liquid/sludge stabilization and chemical fixation of $681,400 \mathrm{~L} /$ day $(180,000$ gallons/day) of waste.

The Laidlaw facility employs approximately 71 workers. Thirty-seven of those workers are waste handling operations workers. The Pinewood facility contains 3 RCRA disposal landfill cells. Fig. 2.2 shows the facility plan of the landfill. The landfill areas consist of approximately 60 ha (148 acres) of land, or 53\% of the entire 113-ha (279-acre) facility. As of June, 1994, Cells I, II, and part of III (III-A) have been filled and closed. The Pinellas waste would be disposed of in the only currently operating cell, RCRA Cell III-B. Waste disposal in Cell III-B began in April, 1994 and has a volume capacity of $359,000 \mathrm{~m}^{3}(470,000$ $\left.\mathrm{yd}^{3}\right)$. The surface area dimensions of Cell III-B are $218 \mathrm{~m} \times 166 \mathrm{~m}$ (715 ft x $545 \mathrm{ft}$ ), which encompasses a total area of 3.6 ha ( 9 acres). As waste is available for disposal, it is placed in the cells in quadrants, the dimensions of which are determined on a daily basis. Most quadrants are approximately $15.2 \mathrm{~m} \times 15.2 \mathrm{~m}$ (50 ft x $50 \mathrm{ft}$ ) (Todd Blake, Laidlaw Environmental Services of South Carolina, personal communication with M. L. Socolof, ORNL, March 11, 1996).

Each RCRA cell has two barriers to prevent the migration of hazardous materials into the groundwater. The first barrier consists of a $0.2-\mathrm{cm}(80-\mathrm{mil})$ high-density polyethylene (HDPE) protective liner atop $1.5 \mathrm{~m}(5 \mathrm{ft})$ of low-porosity compacted clay. The second barrier

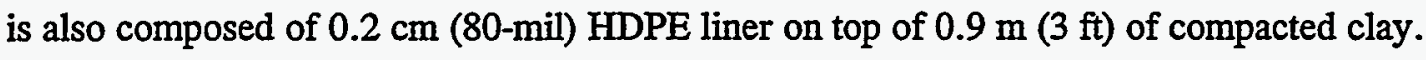
Two leachate collection systems are installed in each cell. The first system is installed directly 


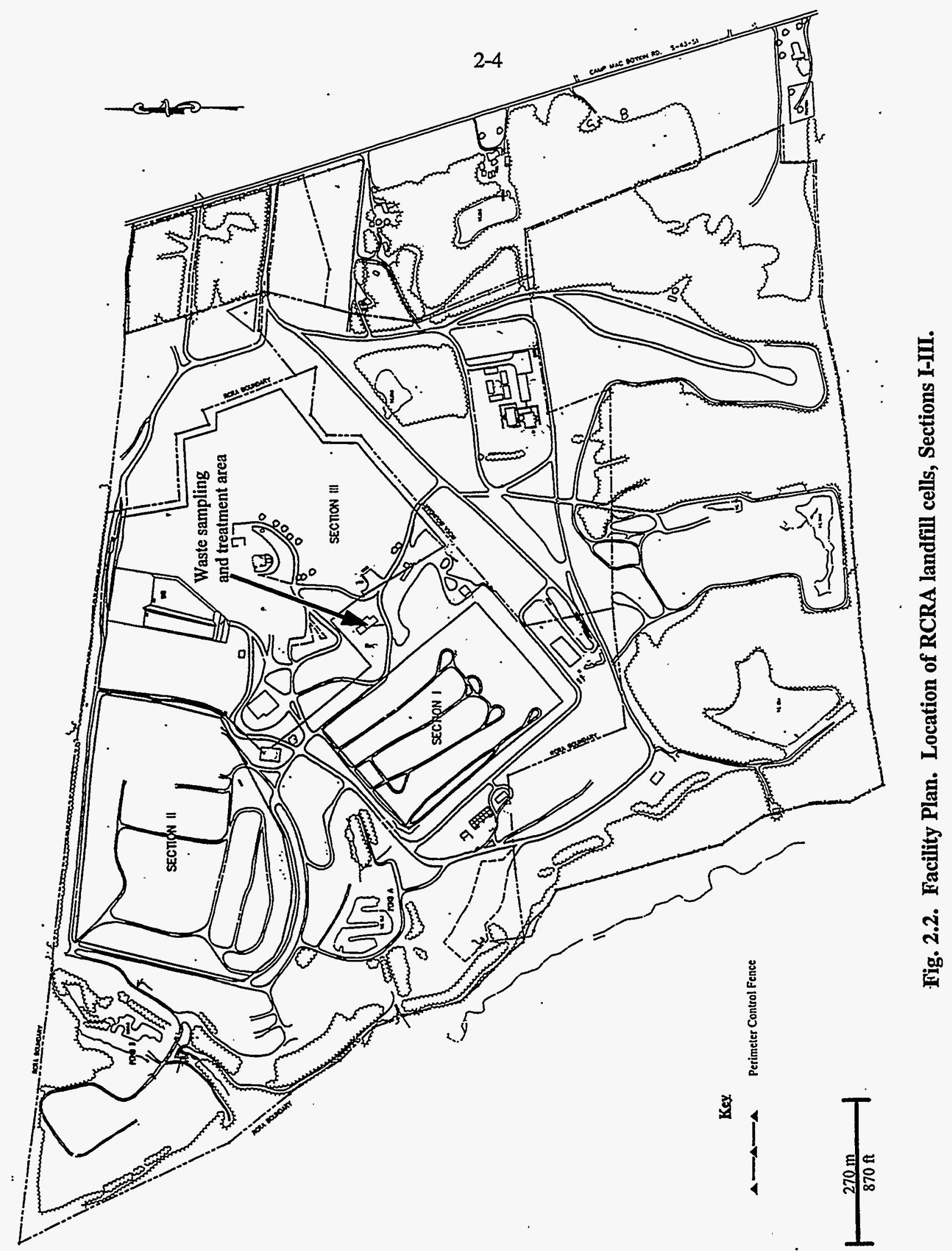


above the primary liner system. This is known as the Leachate Collection and Removal System (LCRS), and it is designed as the primary system for collection and removal of leachate from the landfill. A collection sump within the LCRS is equipped with automated pumps. Between the primary and secondary liner systems is the Leachate Detection, Collection, and Removal System (LDCRS), which is designed to provide additional protection against leakage. Fig. 2.3 shows a cross section of the liner system for Landfill Cell III. The minimum depth from the bottom of the waste material to the uppermost aquifer system is $3 \mathrm{~m} \mathrm{(10} \mathrm{ft).} \mathrm{Once} \mathrm{waste} \mathrm{is}$ placed in the RCRA cells, it is covered with a cap that prevents precipitation from infiltrating into the waste zone. The cover ranges from $1.8 \mathrm{~m}(6 \mathrm{ft})$ to $2.4 \mathrm{~m}(8 \mathrm{ft})$ in thickness. At a

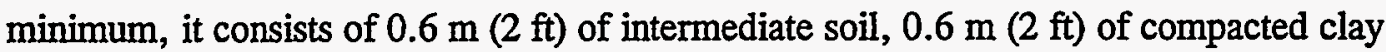
(minimum permeability of $1 \times 10^{-7} \mathrm{~cm} / \mathrm{s}$ ), a $0.16 \mathrm{~cm}$ (60-mil) HDPE synthetic liner, a $0.46-\mathrm{m}$ (18-in.) drainage soil cover, and $15 \mathrm{~cm}$ (6 in.) of topsoil and vegetation (Fig. 2.3). The RCRA permit requires Laidlaw to maintain control over the site and monitor the leachate collection system for a minimum of 100 years after closure of the landfill. The projected final closure date of the land disposal unit is 2030 .

\subsection{Waste Operations}

Operations at the Laidlaw facility for the Pinellas waste include waste sampling, waste stabilization, and waste burial. Each is described below. If approved by the State of South Carolina, the transfer of Pinellas sludge to Laidlaw is expected to be conducted in April or May, 1996. The sludge would be transported in 5 vacuum boxes, each containing approximately $11.5 \mathrm{~m}^{3}\left(15 \mathrm{yd}^{3}\right)$ of sludge. The vacuum boxes have a capacity of $15 \mathrm{~m}^{3}(20$ $\left.\mathrm{yd}^{3}\right)$, leaving $3.8 \mathrm{~m}^{3}\left(5 \mathrm{yd}^{3}\right)$ of headspace. The vacuum boxes are equipped with $61-\mathrm{cm}$ (24-in.) fill hatches and $10-\mathrm{cm}(4-\mathrm{in}$.$) flange drains.$

\subsubsection{Sampling}

A technician would take one representative sample of Pinellas sludge from each of the 5 vacuum boxes. Sampling would be performed through the top fill hatches while the technician is standing on a platform immediately above the vacuum box. The worker would take about 10 minutes to sample any individual vacuum box. Sampling would be conducted during the daytime at ambient temperatures, outside of any walls. All sample analyses are performed at Laidlaw's on-site laboratory. Sample analyses consist of a series of relatively 


\section{TOPLINER SYSTEM DETAIL}

\section{2-6}

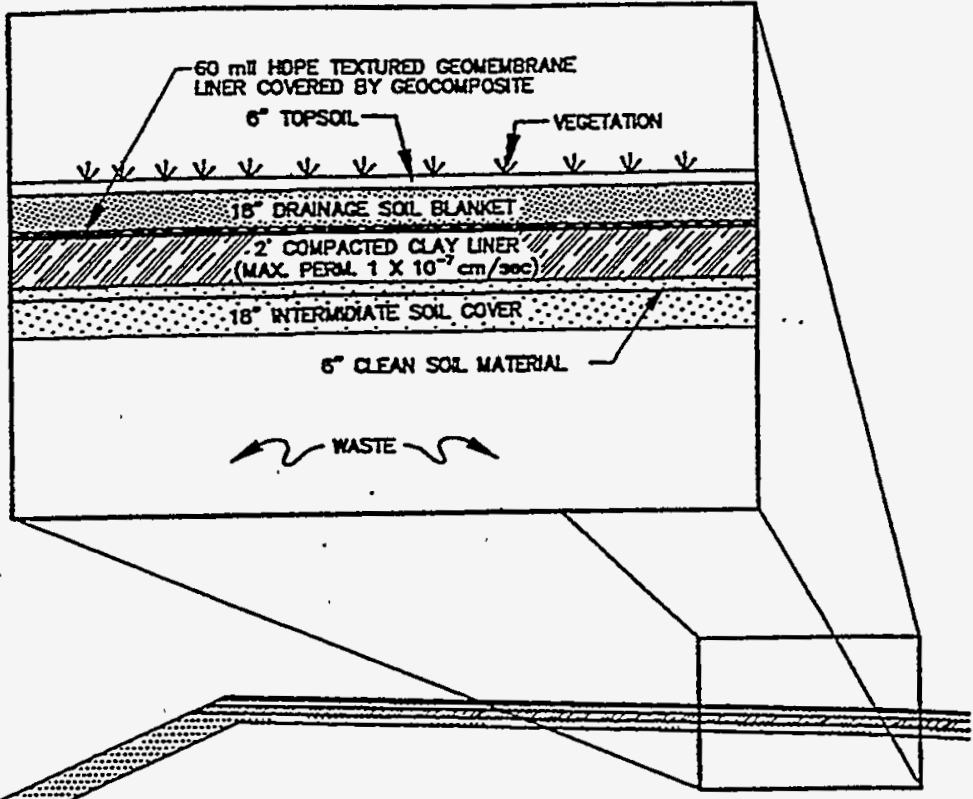

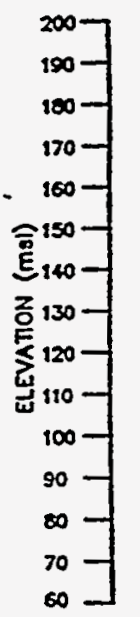

LANDFILL SECTION III 
quick physical tests (e.g., color, appearance, $\mathrm{pH}$, reactivity to acid, etc.) to verify that the material exhibits the same gross physical characteristics that are described in its profile.

Samplers wear half-face cartridge respirators while actually sampling from the vacuum box. The cartridges are combined particulate matter/organic vapor cartridges that also control acid gases, pesticides, mists and fumes, and radioactive particles. The cartridges used with the respirators do not filter tritium; therefore, no credit is given to the use of respirators in the dose analysis. The samplers also wear safety glasses, gloves, hardhats, tyvek suits, and steel-toed boots. Generally there are two samplers on duty at any given time, but each sampler obtains samples from a given vacuum box independently.

\subsubsection{Stabilization}

After a waste shipment is sampled, the vacuum boxes are then driven to the waste treatment area where the sludge is emptied into a mixing pit. The mixing pit has a volume of

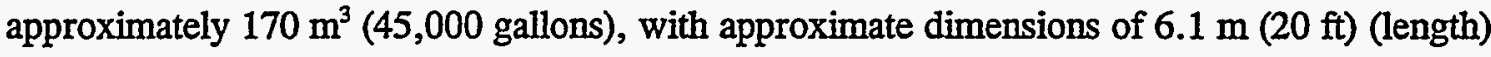
$\times 3 \mathrm{~m}(10 \mathrm{ft})$ (width) $\times 9.3 \mathrm{~m}(31 \mathrm{ft})$ (height). The sludges are mixed with solidification materials such as cement kiln dust and silica to create a grout-like mixture. The volume of the grout is about 2.5 to 3 times greater than the incoming sludge. The stabilizing agents are added by a dump truck and are intended to bind the metals and free water. The sludge mixture is then remotely mixed with a track backhoe bucket by a worker in an enclosed cab of the backhoe. The arm of the track backhoe is approximately 6.1 to $7.6 \mathrm{~m}$ (20 to 25 feet) long and approximately 1.6 to $2.4 \mathrm{~m}$ (6 to $8 \mathrm{feet}$ ) above the ground. The grout-like mixture of Pinellas waste would be transferred into $16,300-\mathrm{kg}$ (18-ton) dump trucks, covered, and transported to and deposited into Landfill Cell III-B.

The expected duration of each stabilization operation is 30 minutes (M. H. Chew \& Associates 1994). Each vacuum box of sludge is stabilized separately. All stabilization is performed during the daytime, out-of-doors, and at ambient temperatures. The reagents that are used react with water in a generally exothermic reaction, which may generate some water vapor. Stabilization personnel wear the same personal protective equipment as that described for the samplers.

\subsubsection{Burial}

At the landfill, trucks dump the stabilized waste into a quadrant in the designated landfill cell. All stabilized materials, once they are actually disposed of, are of a soil- or rock- 
like consistency. Approximately 5 minutes is required to carry out the burial operations (i.e., place the batch of stabilized waste into the landfill cell). One worker, located at ground level, observes the landfilling process. Although placement of the waste in the cell takes only minutes, other landfill workers are present in the vicinity of the cell and could be near the Pinellas waste for approximately four hours per day (M. H Chew \& Associates 1994).

Workers at the landfill wear personal protective equipment while in the vicinity of the waste (same as described for samplers and stabilization workers).

The volume of the Pinellas waste that would be disposed of in Landfill Cell III-B is only a small fraction of the capacity of the cell. The volume of the Pinellas waste is determined from the volume of the incoming sludge. Five vacuum boxes, each containing approximately $11.5 \mathrm{~m}^{3}$ of sludge (Sect. 2.3), equals a total sludge volume of Pinellas waste of about $57.5 \mathrm{~m}^{3}$. With the addition of solidification materials during stabilization, the volume of the waste is increased by 2.5 to 3 times that of the incoming waste (Sect. 2.3.2). Assuming the $57.5 \mathrm{~m}^{3}$ of sludge is tripled, the total volume of the waste is approximately $172 \mathrm{~m}^{3}$. The Pinellas waste would only constitute about $0.05 \%$ of the total volume capacity of landfill Cell III-B of 359,000 $\mathrm{m}^{3}$ (Sect. 2.2).

If the landfill cell is not filled to capacity with the addition of the Pinellas waste, the waste would subsequently be covered with additional waste and/or fill. Only asbestos waste (not applicable to this analysis) is covered daily. Once the cell is completely full, it is covered by a minimum of $1.8 \mathrm{~m}$ ( $6 \mathrm{ft}$ ) of the top liner system, described in Sect. 2.2. 


\section{DOSE ANALYSIS}

Tritium has a radiological half-life of 12.3 years and is a naturally occurring isotope of hydrogen produced by the interaction of cosmic ray protons and neutrons with nitrogen and oxygen atoms. Tritium is also a fission product of nuclear reactors as a result of neutron interaction with coolant additives and other reactor components. Tritium decays to helium-3 by emitting a low-energy beta particle $\left(\mathrm{E}_{\max }=0.0186 \mathrm{MeV}\right)$, precluding tritium from posing an external radiation hazard. However, tritium can pose an internal radiological hazard from inhalation, absorption, or ingestion. Tritium has essentially the same behavior as stable isotopes of hydrogen (i.e., $\mathrm{H}-1$ and $\mathrm{H}-2$ ). This analysis assumes tritium acts as normal hydrogen in the water molecule. The following sections present the dose analyses for worker and public exposures to tritium in the Pinellas F006 sludge. All doses presented are effective dose equivalents ${ }^{1}$. The following dose analysis is based on a representative composite sample of the Pinellas F006 sludge that has a tritium concentration equal to $28.3( \pm 1.4) \mathrm{pCi} / \mathrm{g}$ and that consists of $91 \%$ unbound water (i.e., water that may transport out of the sludge matrix freely). Many assumptions are made throughout this analysis. Those that are referred to as conservative would result in a dose that is either a reasonable upper bound estimate or is higher than expected.

\subsection{Worker Exposure Scenarios}

The radioactive tritium contained in the DOE waste could be released to the atmosphere during (1) sampling and inspection of the waste, (2) stabilization of the waste, and (3) disposal of the waste in the landfill. For the first two operations, the internal dose from inhalation and skin absorption of tritiated water vapor (water vapor where one or both of the hydrogen atoms are replaced by tritium) is calculated assuming the sludge water evaporates into the worker's breathing zone. The models used simulate evaporation from a water spill, and therefore, the tritium activity concentration, by directly estimating the concentration of water vapor in air (M. H. Chew \& Associates 1994). For the third worker activity (disposal), the dose to the burial worker is broken down into acute exposure (during the placement of the waste into the landfill cell) and chronic exposure (from being in the vicinity of the landfilled waste over one year). The acute burial exposure scenario is also calculated using the water spill model, as are the sampling and stabilization scenarios. The chronic burial exposure scenario is calculated using a simple diffusion model. This model accounts for diffusion of tritium upward through the soil

${ }^{1}$ The effective dose equivalent is the weighted sum of the organ-specific doses given in millirem (mrem); 1 mrem equals 0.01 milliSievert (mSv). 
cover to the atmosphere and estimates exposure over a one-year time period. The simple diffusion model does not account for retardation and absorption mechanisms, diffusion through any intervening wastes and cap materials, or radioactive decay during the exposure period. The diffusion model is also compared to the model in the RESRAD computer code, Version 5.60 (Yu et al. 1993), which can also estimate radiation doses from buried waste using a different conceptual model. RESRAD estimates the doses over time from residual radioactivity in the landfilled waste. RESRAD differs from the diffusion model in that it accounts for evapotranspiration of tritium-laden water, leaching, runoff, erosion, and radioactive decay (described in Sect. 3.1.3.2).

Annual doses resulting from the sampling, stabilization, and burial scenarios are calculated using Eq. 3-1. Note that waste sampling, waste stabilization, and acute burial dose scenarios are from short-term exposure scenarios that occur within one year. Therefore, the total dose from each scenario is represented as an annual dose. This is done so that the doses can be compared to annual background levels and annual regulatory limits. Since acute radiation poisoning is of no concern at the dose levels in this analysis, the "acute" exposure scenario doses will be compared to low-level chronic limits. The chronic waste burial and public exposure scenarios are from longer-term exposures that are also presented as annual doses.

$$
H=C_{a} \times I R_{\alpha} \times T \times N \times D C F
$$

where,

$H=$ annual dose $(\mathrm{rem} / \mathrm{y})$,

$C_{a}=$ activity concentration of tritium in the air $\left(\mathrm{Ci} / \mathrm{m}^{3}\right)$,

$I R_{a}=$ inhalation rate of air (worker, light exercise: $4.2 \times 10^{-4} \mathrm{~m}^{3} / \mathrm{s}$ ) (ICRP 1994),

$T=$ exposure time of each operation (s),

$N=$ number of operations $\left(5 \mathrm{y}^{-1}\right)$, and

$D C F=$ inhalation/percutaneous dose conversion factor for tritium $(96 \mathrm{rem} / \mathrm{Ci})$ (EPA 1988; ICRP 1979).

The values of $C_{a}$ and $T$ will vary for each occupational activity. Descriptions and calculations of these scenario-specific components are presented in Sects. 3.1.1, 3.1.2, and 3.1.3. The inhalation rate of a worker during light exercise of $4.2 \times 10^{-4} \mathrm{~m}^{3} / \mathrm{s}$ (ICRP 1994) is used in the occupational exposure scenarios. The number of operations, which would occur during one year, is 5 for the sampling, stabilization, and acute burial scenarios. Eq. 3-1 is modified for the chronic burial scenario and $N$ is not required (see Sect. 3.1.3.2, Eq. 3-18). The DCF for 
tritium in the U. S. Environmental Protection Agency's (EPA's) Federal Guidance Report No. 11 (EPA 1988) is $1.73 \times 10^{-11} \mathrm{~Sv} / \mathrm{Bq}$ (64 rem/Ci). This DCF does not include the dose contribution from absorption of tritiated water vapor through the skin, which amounts to about $50 \%$ of the inhalation dose (ICRP 1979). Therefore, the EPA DCF is increased by $50 \%$ to equal $96 \mathrm{rem} / \mathrm{Ci}$ in this analysis.

\subsubsection{Sampling}

This section uses a water evaporation model to estimate the internal dose to workers from inhalation and absorption of the tritium released to the atmosphere during inspection and sampling of the vacuum boxes containing contaminated sludge. The atmospheric concentration $\left(C_{a}\right)$ in Eq. 3-1 is calculated from the initial concentration of tritium in the vacuum box, the release of tritium out of the vacuum box into the atmosphere, and the dilution of tritium in the atmosphere once released. Due to evaporation, tritiated water vapor fills the vacuum box headspace. First the water vapor concentration in the vacuum box headspace $\left(C_{w, h s}\right)$ is calculated assuming evaporation from a water spill (M. H. Chew \& Associates 1994).

$$
C_{w v, h s}=\left(\frac{M W}{V_{0}}\right)\left(\frac{P_{v a p}}{P_{0}}\right)\left(\frac{T_{0}}{T_{v a p}}\right)
$$

where,

$C_{w v, h s}=$ concentration of water vapor in the vacuum box headspace $\left(\mathrm{g} / \mathrm{m}^{3}\right)$,

$M W=$ molecular weight of water $(18 \mathrm{~g} / \mathrm{mol})$,

$V_{0}=$ volume of 1 mole of gas at standard conditions $\left(0.0224 \mathrm{~m}^{3} / \mathrm{mol}\right)$,

$P_{\text {vap }}=$ saturation water vapor pressure at $33^{\circ} \mathrm{C}(38 \mathrm{~mm} \mathrm{Hg})$,

$P_{0}=$ standard pressure $(760 \mathrm{~mm} \mathrm{Hg})$,

$T_{0}=$ standard temperature $(273 \mathrm{~K})$, and

$T_{\text {vap }}=$ vapor temperature $(\mathrm{K})\left(33^{\circ} \mathrm{C}=306 \mathrm{~K}\right)$.

This analysis conservatively assumes that all the water vapor in the headspace comes from the waste and that all the tritium is in the sludge water. The calculation requires the saturation water vapor pressure as input into the equation, which depends on the temperature (i.e., the higher the temperature, the greater the vapor pressure of water). Sampling activities are expected to occur in April or May. To estimate a reasonable maximum atmospheric dose due to evaporation, this analysis assumes the operations occur in the warmest month (July), when 
evaporation would probably be greatest. July's average daily maximum temperature of $33^{\circ} \mathrm{C}$ $\left(92^{\circ} \mathrm{F}\right)$ corresponds to a vapor pressure of $38 \mathrm{~mm} \mathrm{Hg}$ [Lide (ed.) 1993]. Since operations are expected to occur during the daytime, the average daily maximum temperature is used to calculate the concentration of water vapor in the vacuum box headspace. This is used in lieu of the absolute maximum July temperature since it is unlikely that temperatures would be above that when sampling actually occurs.

Substituting the given values into Eq. 3-2, the water vapor concentration $\left(C_{w v, h s}\right)$ is $36 \mathrm{~g} / \mathrm{m}^{3}$. The concentration of tritium in the vacuum box headspace depends on the amount of tritium in the sludge water and the amount of water vapor in the headspace. Assuming that tritium acts as water vapor, the initial activity concentration in the headspace is calculated as:

$$
C_{h s}^{0}=\left(\frac{A}{f_{w a t}}\right) C_{w v, h s}
$$

where,

$C_{h s}{ }^{0}=$ initial activity concentration of tritium in the vacuum box headspace (before hatch is opened for sampling) $\left(\mathrm{Ci} / \mathrm{m}^{3}\right)$,

$A=$ activity of tritium in sludge $\left(2.83 \times 10^{-11} \mathrm{Ci} / \mathrm{g}\right)$,

$f_{\text {wat }}=$ fraction of sludge that is water (0.91) (dimensionless), and

$C_{w v, h s}=$ mass concentration of water vapor in the vacuum box headspace $\left(\mathrm{g} / \mathrm{m}^{3}\right)$

(Eq. 3-2).

Initial sampling of the sludge revealed an average tritium activity $(A)$ of $2.83 \times 10^{-11} \mathrm{Ci} / \mathrm{g}$ and the fraction of water in the sludge $\left(f_{\text {wat }}\right)$ of 0.91 . Substituting these values and the $C_{w v, h s}$ value from Eq. 3-2 into Eq. 3-3 yields a $C_{h s}{ }^{0}$ of $1.1 \times 10^{-9} \mathrm{Ci} / \mathrm{m}^{3}$. This equation assumes that the tritium is only in the water. Worker exposure occurs when the vacuum box is opened and tritium is released and diluted in the ambient air. The tritium exposure concentration in the air depends on the time-dependent tritium activity in the headspace and the dilution of the headspace volume once exposed to the atmosphere. The time-dependent tritium activity concentration in the headspace $\left[C_{h s}(t)\right]$ due to leakage can then be obtained by integrating the following mass balance equation:

$$
\frac{d C_{h s}(t)}{d t}=-\frac{F C_{h s}^{0}}{V_{h s}}
$$


which yields,

$$
C_{h s}(t)=C_{h s}{ }^{0} \exp \left(\frac{-F t}{V_{h s}}\right)
$$

where,

$C_{h s}(t)=$ tritium activity concentration in the headspace as a function of time $\left(\mathrm{Ci} / \mathrm{m}^{3}\right)$, $C_{h s}{ }^{0}=$ initial tritium activity concentration in the vacuum box headspace $\left(\mathrm{Ci} / \mathrm{m}^{3}\right)$, $F=$ leakage rate $\left(0.058 \mathrm{~m}^{3} / \mathrm{s}\right)$, and

$V_{h s}=$ volume of the vacuum box headspace $\left(3.8 \mathrm{~m}^{3}\right)$.

The leakage rate is scaled from a leakage rate for a $1.9-\mathrm{m}^{2}$ door in calm weather conditions of $0.38 \mathrm{~m}^{3} / \mathrm{s}$ (Strock and Koral 1965 in M. H. Chew \& Associates 1994). The equivalent leakage rate for a $0.61-\mathrm{m}$ (2-ft) diameter circular hatch is $0.058 \mathrm{~m}^{3} / \mathrm{s}$. This would correspond to an exit velocity of $0.20 \mathrm{~m} / \mathrm{s}$ (calculated by dividing the leakage rate by the area of the hatch opening).

The vapor concentration outside the vacuum box is diluted by the air outside the box. The dilution of the headspace volume, when exposed to the atmosphere, is calculated as follows:

$$
D I L=\frac{\left(V_{a}+V_{w}\right)}{V_{a}}
$$

where,

$$
\begin{aligned}
& V_{a}=v \times 1 \mathrm{sec} \times \pi(L / 2)^{2}, \\
& V_{w}=v \times 1 \mathrm{sec} \times u \times 1 \mathrm{sec} \times L,
\end{aligned}
$$

and

$D I L=$ dilution factor (dimensionless),

$V_{a}=$ volume of air that leaks through the opening in $1 \mathrm{~s}\left(\mathrm{~m}^{3}\right)$,

$V_{w}=$ dilution volume of air outside the opening due to wind dispersion in $1 \mathrm{~s}\left(\mathrm{~m}^{3}\right)$,

$v=$ exit velocity of tritiated air from vacuum box $(0.20 \mathrm{~m} / \mathrm{s})$,

$u=$ wind speed (conservatively assume calm conditions: $0.5 \mathrm{~m} / \mathrm{s}$ ), and

$L=$ diameter of vacuum box opening $[0.61 \mathrm{~m}(2 \mathrm{ft})]$.

In calculating $V_{w}$, a vertical mixing depth of the one-second travel distance of contaminated air moving at the exit velocity $(0.20 \mathrm{~m})$ is assumed (i.e., the product of $v \times 1 \mathrm{sec}$ ). This is the 
distance above the opening within which the tritiated water vapor is assumed to be mixed into the outside air passing over the opening. For times beyond 1 second, the velocity of the outside air would have moved the tritiated vapor beyond the breathing zone of the sampling worker. This is a conservative assumption since the individual taking the sample is not likely

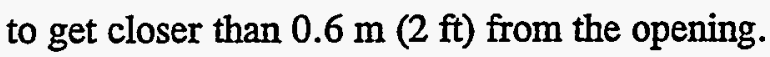

A calm wind speed $(u)$ of $0.5 \mathrm{~m} / \mathrm{s}$ is used. This is a conservative assumption since the wind speed would likely be higher [the annual average wind speed in Columbia, South Carolina is approximately $3 \mathrm{~m} / \mathrm{s}$ (DOC 1995)] and because wind speed and concentration are inversely related (i.e., the lower the wind speed, the lower the dilution and consequently, the higher the concentration of tritium in the air). Using the given values of $v, u$, and $L$ in Eq. 3-6, the values of $V_{a}$ and $V_{w}$ equal $0.058 \mathrm{~m}^{3}$ and $0.060 \mathrm{~m}^{3}$, respectively. Subsequently, the dilution factor is 2.0.

The concentration of tritium in the air is the concentration in the headspace divided by the dilution factor.

$$
C_{a}=\frac{C_{h s}(t)}{D I L}
$$

where,

$C_{a}=$ activity concentration of tritium in the air $\left(\mathrm{Ci} / \mathrm{m}^{3}\right)$,

$$
\begin{aligned}
& C_{h s}(t)=\quad \text { time-dependent activity concentration of tritium in the vacuum box } \\
& \text { headspace }\left(\mathrm{Ci} / \mathrm{m}^{3}\right) \text {, and }
\end{aligned}
$$

$D L=$ dilution factor from surrounding outside air (2.0; Eq. 3-6).

The concentration in the outside air is then calculated by combining Eqs. 3-5 and 3-7,

$$
C_{a}=\frac{C_{h s}{ }^{0} \exp \left(\frac{-F t}{V_{h s}}\right)}{D I L} .
$$

This concentration is then used to calculate the dose to the sampler. Since the concentration in the air is a function of time, the dose is integrated over the sampling exposure time. This is shown below as the definite integral of Eq. 3-1 from time zero to time $T$. 


$$
H=\int_{0}^{T} C_{a}(t) \times I R_{a} \times N \times D C F d t
$$

where,

$H=$ annual dose (rem/y),

$T=$ exposure time of each operation $(600 \mathrm{~s})$,

$C_{a}(t)=$ activity concentration of tritium in the air as a function of time $\left(\mathrm{Ci} / \mathrm{m}^{3}\right)$,

$I R_{a}=$ inhalation rate of air (worker, light exercise: $4.2 \times 10^{-4} \mathrm{~m}^{3} / \mathrm{s}$ ) (ICRP 1994),

$N=$ number of operations $\left(5 \mathrm{y}^{-1}\right)$, and

$D C F=$ inhalation/percutaneous dose conversion factor for tritium $(96 \mathrm{rem} / \mathrm{Ci})(\mathrm{EPA}$ 1988; ICRP 1979).

The definite integral from time zero to time $T$ is expressed as

$$
H=\left(\frac{C_{h s}^{0}}{D I L}\right)\left(\frac{V_{h s}}{F}\right)\left[1-\exp \left(\frac{-F T}{V_{h s}}\right)\right] I R_{a} \times N \times D C F .
$$

The sampling exposure scenario assumes one worker conducts all 5 sampling operations $(N=5)$ and each operation takes 10 minutes $(T=600 \mathrm{~s})$. Substituting in each term given above into Eq. 3-10, and converting rem to mrem, the annual dose to one worker from sampling all the Pinellas waste is $7.2 \times 10^{-6} \mathrm{mrem} / \mathrm{y}$.

\subsubsection{Stabilization}

The Pinellas sludge would be placed into the open stabilization tank for treatment. Sludge in each of the 5 vacuum boxes is assumed to be stabilized separately. For this dose analysis, the tritium is assumed to behave as normal hydrogen in the water molecule, and bind into the water/reagent matrix. During stabilization, tritium may be released to the atmosphere as a result of evaporation of the water content in the sludge. The potential exposure would be from tritiated water vapor above the tank. The concentration of tritiated water vapor in the air above the tank $\left(C_{\partial}\right)$ is calculated by estimating the concentration of water vapor above the tank, for which the source term is the evaporation of water from the tank and the removal term is 
advection in the wind and ambient air. The mass balance equation for the concentration of water vapor above the tank, representing the time-dependent concentration in relation to the source term and the removal term is as follows:

$$
\frac{d C_{w v}}{d t}=\frac{A_{t} Q}{V}-\frac{u A_{s} C_{w v}}{V}
$$

where,

$C_{w v}=$ mass concentration of water vapor in a volume of air above the stabilization tank $\left(\mathrm{g} / \mathrm{m}^{3}\right)$

$A_{t}=$ surface area of the top of the stabilization $\operatorname{tank}\left(\mathrm{m}^{2}\right)\left(6.1 \mathrm{~m} \times 3.0 \mathrm{~m}=18.3 \mathrm{~m}^{2}\right)$,

$Q=$ water evaporation rate per unit area $\left(\mathrm{g} / \mathrm{s}-\mathrm{m}^{2}\right)$,

$V=$ volume of waste in stabilization $\operatorname{tank}\left(\mathrm{m}^{3}\right)$,

$u=$ wind speed (assume calm winds, $0.5 \mathrm{~m} / \mathrm{s}$ ), and

$A_{s}=$ cross sectional area of a side of mixing volume above the mixing stabilization $\operatorname{tank}\left(\mathrm{m}^{2}\right)\left(3.0 \mathrm{~m} \times 3 \mathrm{~m}=9 \mathrm{~m}^{2}\right)$.

Assuming steady state conditions, the time-dependant term in Eq. 3-11 is set equal to zero. This results in the following simplified equation,

$$
C_{w v}=\frac{A_{t} Q}{u A_{s}}
$$

This analysis assumes a certain mixing volume above the stabilization tank, the dimensions of which are used to calculate the top and cross-sectional surface areas. The length and width of the mixing volume are assumed to be the same as the length and width dimensions of the stabilization tank (i.e., $6.1 \mathrm{~m} \mathrm{x} 3.0 \mathrm{~m}$ ). Therefore, the surface area of the top of the $\operatorname{tank}\left(A_{t}\right)$ equals $6.1 \mathrm{~m} \times 3.0 \mathrm{~m}$, or $18.3 \mathrm{~m}^{2}$. The height of the mixing zone above the tank is assumed to be $3 \mathrm{~m}$ [about the same as the height used in the 1994 dose assessment for Laidlaw (M. H. Chew \& Associates 1994)]. The $3 \mathrm{~m}$ is chosen to represent a mixing volume above the tank within which the exposed worker may be located. A larger height, and therefore larger mixing volume, would result in smaller doses and would therefore be less conservative. The sensitivity analysis in Sect. 3.3 shows that using a smaller height of $0.3 \mathrm{~m}(1 \mathrm{ft})$ would increase the dose by a factor of 10 , but does not change the conclusions that the dose is far below a dose of concern (see Sect. 4). The cross-sectional area $\left(A_{s}\right)$ of the mixing volume is then calculated 
with the height and width, $3.0 \mathrm{~m} \mathrm{x} 3 \mathrm{~m}$, or $9 \mathrm{~m}^{2}$. A conservative, calm wind speed $(u)$ of $0.5 \mathrm{~m} / \mathrm{s}$ is used. The evaporation rate is conservatively estimated below based on a water spill (EPA 1987), which uses the ideal gas law and wind speed.

$$
Q=\frac{M W K P_{v a p}}{R T_{v a p}}
$$

where,

$$
K=0.25 u^{0.78}
$$

and

$$
\begin{aligned}
& Q=\text { water evaporation rate per unit area }\left(\mathrm{g} / \mathrm{s}-\mathrm{cm}^{2}\right), \\
& M W=\text { molecular weight of water }(18 \mathrm{~g} / \mathrm{mol}), \\
& K=\text { gas phase mass transfer coefficient }(\mathrm{cm} / \mathrm{s}), \\
& P_{\text {vap }}=\text { saturation vapor pressure }\left(38 \mathrm{~mm} \mathrm{Hg} \text { at } 33^{\circ} \mathrm{C}\right), \\
& R=\text { gas constant } 62,358 \mathrm{~mm} \mathrm{Hg}-\mathrm{cm}^{3} / \mathrm{mol}-\mathrm{K}, \\
& T_{\text {vap }}=\text { vapor temperature }(\mathrm{K})\left(33^{\circ} \mathrm{C}=306 \mathrm{~K}\right) \text {, and } \\
& u=\text { wind speed }(0.5 \mathrm{~m} / \mathrm{s}) .
\end{aligned}
$$

Substituting the values given above into Eq. 3-13, the water evaporation rate per unit area $(Q)$ is $5.2 \times 10^{-6} \mathrm{~g} / \mathrm{s}-\mathrm{cm}^{2}$. To substitute $Q$ into Eq. $3-12$, the value must be converted to $0.052 \mathrm{~g} / \mathrm{s}-$ $\mathrm{m}^{2}$ so that the units are consistent. Substituting $Q$ into Eq. 3-12 yields a water vapor concentration above the stabilization tank $\left(C_{w v}\right)$ of $0.21 \mathrm{~g} / \mathrm{m}^{3}$. Substituting that water vapor concentration value into the right hand side of Eq. 3-3 yields a tritium concentration in the air above the tank $\left(C_{a}\right)$ for the stabilization scenario, represented as

$$
C_{a}=\left(\frac{A}{f_{w a t}}\right) C_{w v}
$$

where,

$C_{a}=$ activity concentration of tritium in a volume of air above the stabilization tank $\left(\mathrm{Ci} / \mathrm{m}^{3}\right)$,

$A=$ activity of tritium in sludge $\left(2.83 \times 10^{-11} \mathrm{Ci} / \mathrm{g}\right)$,

$f_{\text {wat }}=$ fraction of sludge that is water (0.91) (dimensionless), and 
$C_{w v}=$ mass concentration of water vapor in a volume of air above the stabilization tank $\left(\mathrm{g} / \mathrm{m}^{3}\right)$.

The concentration of tritium in the air, to which a worker is exposed, is calculated to be $6.6 \times 10^{-12} \mathrm{Ci} / \mathrm{m}^{3}$. This concentration is then substituted into Eq. 3-1 to calculate the dose. The exposure time is assumed to be 30 minutes ( $1800 \mathrm{~s}$ ) per vacuum box of sludge, which is the time for stabilization activities and transfer to the disposal cell. The same worker also is assumed to conduct all 5 stabilization operations $(N=5)$. The calculated dose from Eq. 3-1 for stabilization operations, after being converted from rem to mrem, is $2.4 \times 10^{-6} \mathrm{mrem} / \mathrm{y}$.

\subsubsection{Burial}

\subsubsection{Acute exposure}

This analysis uses the same water evaporation model used in the stabilization scenario. During burial operations, a worker would be in an enclosed tractor and would place a load of waste into a specific quadrant of the landfill cell. Placement is expected to take 5 minutes, based on past experience (M. H. Chew \& Associates 1994). Landfill workers walk in the vicinity of the waste to direct waste placement. The dose to a landfill worker is calculated assuming a waste-placement worker is in the vicinity of the waste for 5 minutes during the placement of all 5 loads of stabilized waste.

As with the sampling and stabilization analyses, exposure to tritium in the waste could occur as the result of evaporation of the tritiated water content in the waste. A conservative approach is to assume that the evaporation rate of the tritiated water is based on a water spill instead of water within the grout matrix. The estimated airborne tritium concentration is calculated using Eqs. 3-12, 3-13, and 3-15. The differences between the equations used in the stabilization scenario and this scenario are that the surface areas and cross-sectional areas are from the dimensions of the landfill cell as opposed to those from the stabilization tank:

$$
\begin{aligned}
& A_{\mathrm{t}}=15.2 \mathrm{~m} \times 15.2 \mathrm{~m}=231 \mathrm{~m}^{2}\left(50 \mathrm{ft} \times 50 \mathrm{ft}=2500 \mathrm{ft}^{2}\right) \text { and } \\
& A_{s}=15.2 \mathrm{~m} \times 3.0 \mathrm{~m}=45.6 \mathrm{~m}^{2}\left(50 \mathrm{ft} \times 9.8 \mathrm{ft}=490 \mathrm{ft}^{2}\right)
\end{aligned}
$$

The length and width are from the surface area dimensions of a quadrant in RCRA Cell III-B (see Sect. 2.2). The mixing zone height is assumed to be the same size as that in the stabilization scenario $(3.0 \mathrm{~m})$. This would represent a reasonable mixing zone that would incorporate a worker's breathing zone. 
The water evaporation rate per unit area $(Q)$ is the same as calculated for the stabilization scenario in Eq. 3-13. The value of $Q\left(0.052 \mathrm{~g} / \mathrm{s}-\mathrm{m}^{2}\right)$ is substituted into Eq. 3-12 with the $A_{t}$ and $A_{s}$ values above to estimate the concentration in the water vapor above the landfill cell $\left(C_{w v}\right)$. This value is $0.53 \mathrm{~g} / \mathrm{m}^{3}$. The concentration of tritium in the air above the landfill cell $\left(C_{a}\right)$ is then calculated using Eq. 3-15. This value is $1.7 \times 10^{-11} \mathrm{Ci} / \mathrm{m}^{3}$. Finally, $C_{a}$ is substituted into Eq. 3-1, assuming the time of exposure $(T)$ is 5 minutes (300 s) per load of waste, the number of loads $(N)$, which would occur within one year is 5 , and the same worker is exposed to all 5 loads. The resulting annual dose, after converting rem to mrem in the equation, is $9.9 \times 10^{-7} \mathrm{mrem} / \mathrm{y}$.

\subsubsection{Chronic exposure}

The chronic burial scenario calculates exposure to a landfill worker after the waste is covered. Two models were used to calculate the doses from chronic exposure. The first model calculates the exposure to a worker over a year, approximating tritium diffusing onedimensionally (i.e., upward only) through the covered waste. For comparison, the second calculation uses the RESRAD model, which accounts for mechanisms such as transpiration, leaching, runoff, erosion, and radioactive decay. The RESRAD model determines exposure over many years.

The release of tritium upward from the buried waste into the air is first estimated in this section using a simple one-dimensional diffusion model. A landfill worker, while working in the vicinity of the buried waste, is assumed to be exposed to tritium that has diffused out of the grouted sludge. For the purposes of this analysis, the waste is assumed to be covered with 1.8 $\mathrm{m}(6 \mathrm{ft})$ of soil, which is the minimum cover depth at the Laidlaw landfill. Also, all the waste is assumed to be placed in a quadrant measuring $15.2 \mathrm{~m} \mathrm{x} 15.2 \mathrm{~m}$ (50 ft x $50 \mathrm{ft}$ ) (Sect. 2.2). In this simple calculation, absorption mechanisms in the soil and waste and the barrier properties of the synthetic liner are ignored.

Tritium is assumed to be transported to the soil surface by diffusion in the vapor phase. The mass transfer of water vapor is assumed to be a first-order, linear process and is assumed to occur from the top of the waste to the soil surface. The one-dimensional diffusion calculation can be expressed as follows (Kirkham and Powers 1972 in M. H. Chew \& Associates 1994):

$$
Q=\frac{-D_{v s}\left(C_{v a}-C_{v s}\right)}{L}
$$


and

$$
D_{v s}=0.66 P D_{v a}
$$

where,

$Q=$ mass transfer rate of water vapor $\left(\mathrm{g} / \mathrm{s}-\mathrm{cm}^{2}\right)$,

$C_{v a}=$ water vapor concentration at the surface of the soil cover $\left(0 \mathrm{~g} / \mathrm{cm}^{3}\right)$,

$C_{v s}=$ water vapor concentration at the bottom of the soil cover $\left(\mathrm{g} / \mathrm{cm}^{3}\right)$,

$L=$ diffusion distance (cover depth) $(180 \mathrm{~cm})$,

$D_{v a}=$ diffusion coefficient of water vapor in air $\left(0.239 \mathrm{~cm}^{2} / \mathrm{s}\right)$,

$D_{v s}=$ diffusion coefficient of water vapor in soil (grouted waste) $\left(\mathrm{cm}^{2} / \mathrm{s}\right)$, and

$P=$ effective porosity of waste (dimensionless) (0.2).

The term $C_{v s}$ is calculated using the same equation (Eq. 3-2) used to calculate $C_{v w, h s}$ for the sampling scenario. To calculate $C_{v s}$, the value of $T_{v a p}$ is assumed to be the temperature of the waste. Assuming the temperature of the waste is the same as soil, an average summer soil temperature at a depth of $1.8 \mathrm{~m}(6 \mathrm{ft})$ is used as a conservative estimate to determine the water vapor concentration. This is conservative because the higher the temperature, the greater the vapor pressure and subsequently, the greater the vapor concentration and dose. The average summer soil temperature at a depth of $1.8 \mathrm{~m}$ is about $21^{\circ} \mathrm{C}$ (Baver $1956 \mathrm{in} \mathrm{M}$. H. Chew \& Associates 1994). The corresponding water vapor pressure is about $20 \mathrm{~mm} \mathrm{Hg}$ [Lide (ed.) 1993]. Thus, using Eq. 3-2, $C_{v s}$ equals $18.7 \mathrm{~g} / \mathrm{m}^{3}$. To use this parameter in Eq. 3-16 as $C_{v s}$, the value must be converted to $1.87 \times 10^{-5} \mathrm{~g} / \mathrm{cm}^{3}$. For this diffusion calculation, $C_{v a}$ is conservatively assumed to equal zero. This is conservative because the equilibrium water vapor concentration at the surface of the soil is likely to be slightly higher.

To calculate the term $D_{v s}$, Eq. 3-17 uses a $P$ value of 0.2 , which assumes the porosity is similar to that of a silt (M. H. Chew \& Associates 1994; Yu et al. 1993, p. 210). The sensitivity analysis (Sect. 3.3) evaluates the effects of using of this value. The $D_{v a}$ of 0.239 $\mathrm{cm}^{2} / \mathrm{s}$ and $L$ of $1.8 \mathrm{~m}$ of soil cover are also substituted into Eq. 3-17 to obtain a $D_{v s}$ value of $0.0315 \mathrm{~cm}^{2} / \mathrm{s}$. Substituting the values given for each variable into Eq. 3-16, the mass transfer rate $(Q)$ equals $3.27 \times 10^{-9} \mathrm{~g} / \mathrm{s}-\mathrm{cm}^{2}$. Converting this value to units in terms of square meters (i.e., $3.27 \times 10^{-5} \mathrm{~g} / \mathrm{s}-\mathrm{m}^{3}$ ), $Q$ is substituted into Eq. $3-12$ in place of the water evaporation rate to calculate the equilibrium concentration of water vapor in the air $\left(C_{w v}\right)$. The wind speed $(u)$ is assumed for calm conditions $(0.5 \mathrm{~m} / \mathrm{s})$. The surface area $\left(A_{t}\right)$ from which the vapor diffuses is assumed to be the surface area of the RCRA cell $\left(15.2 \mathrm{~m} \times 15.2 \mathrm{~m}=231 \mathrm{~m}^{2}\right)$. The crosssectional area of the mixing volume $\left(A_{s}\right)$ is $15.2 \mathrm{~m} \mathrm{x} 3 \mathrm{~m}=45.6 \mathrm{~m}^{2}$, which assumes a mixing 


\section{3-13}

height of $3 \mathrm{~m}$, as in the previous sections of this analysis. The value of $C_{w r}$ from Eq. 3-12 consequently equals $3.3 \times 10^{-4} \mathrm{~g} / \mathrm{m}^{3}$.

This water vapor concentration is then substituted into Eq. 3-15 to yield the activity concentration of tritium in a volume of air above the buried waste form $\left(C_{a}\right)$. The result is $1.0 \times 10^{-14} \mathrm{Ci} / \mathrm{m}^{3}$. This is then substituted into a modified Eq. 3-1 to yield the dose. The product of the time of exposure $(T)$ and the number of operations per year $(N)$ in Eq. 3-1 are replaced with the fraction of time exposed $\left(f_{e t}\right)$ over a year for the burial scenario to account for the fact that all the waste is already in the cell and the number of operations per year is not needed:

$$
H=C_{a} \times I R_{a} \times f_{e t} \times D C F
$$

where,

$H=$ annual dose (rem/y),

$C_{a}=$ activity concentration of tritium in the air $\left(\mathrm{Ci} / \mathrm{m}^{3}\right)$,

$I R_{a}=$ intake rate of air (inhalation rate) (standard man: $4.17 \times 10^{-4} \mathrm{~m}^{3} / \mathrm{s}$ ) (ICRP 1994),

$f_{e t}=$ fraction of time exposed $\left(3.6 \times 10^{6} \mathrm{~s} / \mathrm{y}\right)$, and

$D C F=$ inhalation/percutaneous dose conversion factor for tritium $(96 \mathrm{rem} / \mathrm{Ci})(\mathrm{EPA}$ 1988; ICRP 1979).

A worker is assumed to be exposed to airborne releases from the waste four hours a day for 250 work days in a year $\left(3.6 \times 10^{6} \mathrm{~s} / \mathrm{y}\right)$. The annual dose, without accounting for radioactive decay, is equal to $1.5 \times 10^{-6}$ mrem. Before exposure would occur, tritium would decay during the diffusion process. The time of diffusion $\left(t_{\text {diff }}\right)$ through the soil can be calculated assuming the diffusive velocity is uniform and it is approximated as one-dimensional, first-order and linear (Lombardi and Socolof 1996):

$$
t_{d i f f}=\frac{L^{2}}{D_{v s}}
$$

The terms of this equation are defined in Eq. 3-16. Using Eq. 3-19, where $L$ equals $180 \mathrm{~cm}$ (Eq. 3-16) and $D_{v s}$ equals about $0.03 \mathrm{~cm}^{2} / \mathrm{s}$ (Eq. 3-17), the diffusion time is $1 \times 10^{6} \mathrm{~s}$ (12 days). Radioactive decay of tritium is negligible during such a short time, which can be calculated using the following equation: 


$$
r_{\text {decay }}=\exp \left(\frac{-\ln (2) t}{t_{1 / 2}}\right)
$$

where,

$$
\begin{aligned}
& r_{\text {decay }}=\text { fraction of tritium remaining after radioactive decay during time } \\
& \quad t \text { (dimensionless), } \\
& t=\text { time over which decay occurs (y), and } \\
& t_{I / 2}=\text { half-life of tritium (12.3 y). }
\end{aligned}
$$

Calculating the decay of tritium during the diffusion time of 12 days $(0.03 \mathrm{y})$ exposure time results in an $r_{\text {decay }}$ of 0.998 . This does not change the calculated dose of $1.5 \times 10^{-6} \mathrm{mrem} / \mathrm{y}$ within the precision of this analysis.

To compare the results of the simple diffusion model with another model, the RESRAD code (Yu et al. 1993) was also used to calculate a chronic inhalation dose to a landfill worker. Using RESRAD, the maximum potential exposure is estimated assuming tritium is released to the atmosphere from the grouted sludge. RESRAD uses a similar tritium model based on specific activity that is used above. The model is based on the fact that tritium has essentially the same chemical behavior as stable isotopes of hydrogen (i.e., $\mathrm{H}-1, \mathrm{H}-2$ ). Therefore, tritium occurs in the environment in concentrations that are proportional to the ratio of tritium to stable hydrogen in the environment (Yu et al. 1993). Furthermore, the circulation of tritium in the environment generally is expected to closely follow that of water. However, RESRAD does not model diffusion of tritium through the soil cover. The model assumes tritium acts as water and calculates the amount of tritium in the environment as water vapor from evaporation. The model also accounts for evapotranspiration, leaching, runoff, erosion, and radioactive decay.

To calculate the evaporation of tritium from the waste into the air, the dimensions of the waste are needed. This is calculated from the total volume of the waste of $172 \mathrm{~m}^{3}$ (Sect. 2.3.3) and the surface area of the quadrant in the landfill cell of $15.2 \mathrm{mx} 15.2 \mathrm{~m}$ (Sect. 2.2). Assuming the waste is spread over the entire surface of the quadrant, the dimensions of the waste would be $15.2 \mathrm{~m} \mathrm{x} 15.2 \mathrm{~m} \mathrm{x} 0.74 \mathrm{~m}$. Tritium is assumed to be released to the atmosphere from the grouted waste form. The worker is assumed to be exposed to the waste form after it is covered with $1.8 \mathrm{~m}$ of soil in the RCRA cell. The waste form dimensions are used to determine the concentration of tritium in the soil, which is then used to calculate a concentration in the air. RESRAD calculates an air concentration by accounting for the 
humidity in the air, the density of the waste and of the soil cover, the hydraulic conductivity of the waste, the erosion rate of the cover soil and the waste, the porosity of the waste, the precipitation rate, the irrigation rate, and evapotranspiration and runoff characteristics. All parameter values are presented in Appendix A, Sect. A.1.

The mean annual absolute humidity for the region of the country where the Laidlaw facility lies is $10.6 \mathrm{~g} / \mathrm{m}^{3}$. It is on the border of an area that ranges from 7.6 to $11.5 \mathrm{~g} / \mathrm{m}^{3}$ ( $\mathrm{Yu}$ et al. 1993, p. 310). The density of the waste is assumed to be about $1.2 \mathrm{~g} / \mathrm{cm}^{3}$, and the hydraulic conductivity of the waste is assumed to be $10 \mathrm{~m} / \mathrm{y}$. These values are the same as those of similar Pinellas waste that underwent similar treatment that was sent to South Carolina for disposal in 1992 (M. H. Chew \& Associates 1994). The erosion rate of the cover and the contaminated zone of $0.001 \mathrm{~m} / \mathrm{y}$ (the RESRAD default value) is used and is insensitive to the calculated dose and, therefore, a more precise value is not needed for this analysis.

The porosity, precipitation rate, irrigation rate, evapotranspiration coefficient, and runoff coefficient are used to calculate the infiltration of water through the contaminated zone to estimate leaching. As described for the diffusion model, this analysis assumes the contaminated zone effective porosity is 0.2 (Yu et al. 1993, p. 210). This corresponds to a total porosity of the waste of 0.4 for something resembling a silt. The annual rainfall in Columbia is approximately $1.27 \mathrm{~m}$ (DOC 1995). Due to the relatively high precipitation rate at the site, irrigation was assumed to be zero. The introduction of more water would increase leaching and thus decrease the atmospheric release of tritium from the waste. Therefore, assuming no irrigation is conservative. The runoff coefficient (0.5) assumes the land is a level, clay surface with pasture grass (i.e., cultivated lands, as opposed to woodlands) ( $\mathrm{Yu}$ et al. 1993, p. 199; M. H. Chew \& Associates 1994). The evapotranspiration coefficient, which can vary between 0 and 1 , was estimated to be 0.74 in the 1994 dose analysis for Pinewood (M. H Chew \& Associates 1994) and is also used in this analysis.

The landfill cover depth in the diffusion model was assumed to be $1.8 \mathrm{~m}(6 \mathrm{ft})$. The RESRAD code uses a reference cover depth of $0.3 \mathrm{~m}$, above which it assumes no tritium escapes through this distance and into the atmosphere. Therefore, the minimum anticipated depth of the cover material at Laidlaw of $1.8 \mathrm{~m}$ would result in a dose of zero and is not used in the analysis. The maximum depth of $0.3 \mathrm{~m}$ is used to carry out the RESRAD run.

As in the diffusion model, a worker conservatively is assumed to be exposed to atmospheric releases from the waste four hours a day for 250 work days in a year $\left(3.6 \times 10^{6}\right.$ $s / y)$. The inhalation rate that is used also assumes conditions of a worker conducting light exercise (4.2 $\times 10^{-4} \mathrm{~m}^{3} / \mathrm{s}$ ) (ICRP 1994). The internal dose conversion factor of $96 \mathrm{rem} / \mathrm{Ci}$ for inhalation and absorption is also used (EPA 1988; ICRP 1979). Appendix A lists all the specific input parameters used by the RESRAD code to calculate the burial worker's dose. The 
resulting annual dose from inhalation (after one year of exposure) is $8.7 \times 10^{-6} \mathrm{mrem} / \mathrm{y}$. To compare more accurately this result to the diffusion model, the cover depth in the diffusion model was modified to $0.3 \mathrm{~m}$. This results in a dose of $8.9 \times 10^{-6} \mathrm{mrem} / \mathrm{y}$, nearly the same value as determined by RESRAD. The diffusion model has been selected for the chronic burial worker exposure in this analysis because (1) the RESRAD model would have actually calculated a dose of zero with the appropriate $1.8 \mathrm{~m}$ cover depth, and (2) with the same cover depth, the dose from the diffusion model was slightly higher (more conservative). The RESRAD results can simply be used to show that a slightly different model will have similar results to the diffusion model, and that the dose from buried waste is very low and probably very close to zero.

\subsection{Public Exposure Scenario}

The most likely radiation dose to the public from the disposal of Pinellas waste at the Laidlaw facility is from tritium migrating into the groundwater and being consumed directly by humans. Other but less likely exposure routes are through ingestion of foodstuffs (e.g., milk, meat, fish) that have been contaminated with the water containing tritium. Exposure through inhalation of tritium released into the atmosphere is even less likely than exposure through groundwater-dependent pathways for the following reasons. Members of the public would be restricted from gaining access to the landfill for many years (through 2130 , or 100 years after landfill closure), the half-life of tritium is relatively short (12.3 years), and the site has a relatively high annual precipitation which would tend to reduce the volatilization of tritium and cause it to leach into the groundwater more readily.

The public dose is calculated using RESRAD (Yu et al. 1993), which assumes a hypothetical maximally exposed individual, who ingests water taken from a well that is at the downgradient edge of the contaminated area. The member of the public is assumed to consume water from a well contaminated with tritium that has leached from the landfill. To estimate exposure from contaminated groundwater, a nondispersion model is used that assumes the unsaturated zone consists of one or more horizontal homogeneous strata, the saturated zone is a single homogeneous stratum, water withdrawal introduces only a minor perturbation in the water flow, and there is no dispersivity. These assumptions match hydrogeological conditions at the Laidlaw site. Ingestion of foodstuffs also contaminated with Pinellas-derived tritium results in doses that are much less than the dose from the water ingestion pathway and therefore are not included in this discussion.

This dose analysis conservatively assumes exposure begins immediately after the waste is put in place and covered. This assumption ignores (1) the required 100-year institutional 
control period stipulated in the facility's RCRA permit and (2) the fact that the landfill facility will likely operate for until 2030 , during which time the leachate collection system will be in operation.

The same site-specific parameters used for the burial worker assessment are used to calculate the public dose. These include parameters associated with the site and the contaminated zone characteristics (e.g., area of contaminated zone, erosion rates, waste porosity, contaminated zone hydraulic conductivity, precipitation, evapotranspiration coefficient, etc.). The one exception is that the appropriate cover depth of $1.8 \mathrm{~m}$ is used. Additional parameters are also needed to calculate the dose from the water pathway to the public. All parameter values are listed in Appendix A, Sect. A.2.

Most of the remaining parameters are related to the hydrogeology of the unsaturated and saturated zones. The unsaturated and saturated zone soil type is characterized as a claystone. The hydraulic conductivity of the unsaturated zone is between $10^{-3}$ and $10^{-5} \mathrm{~cm} / \mathrm{s}$ and of the saturated zone is between $1.06 \times 10^{-2}$ and $7.87 \times 10^{-5} \mathrm{~cm} / \mathrm{s}$ (see Sect. 2.1). The highest value was conservatively chosen for the hydraulic conductivity of the unsaturated zone, as this would allow more tritium to reach the aquifer, which results in a higher dose. The saturated zone hydraulic conductivity used in the model is not linear with dose. At conductivities in the lower range of the saturated zone [e.g., $7.87 \times 10^{-5} \mathrm{~cm} / \mathrm{s}(24.8 \mathrm{~m} / \mathrm{y})$ ], the dose increases with an increase in hydraulic conductivity. At the upper range of the saturated zone hydraulic conductivity, dose decreases with increasing hydraulic conductivity. The hydraulic conductivity that results in the maximum dose is about $1.05 \times 10^{-3} \mathrm{~cm} / \mathrm{s}(330 \mathrm{~m} / \mathrm{y})$, which is related to other factors such as the well pumping rate and the infiltration rate (which is affected by precipitation, runoff, and evapotranspiration) (Yu et al. 1993, p. 213-214). To be conservative, this hydraulic conductivity resulting in the maximum dose was chosen for this analysis.

The length of the aquifer parallel to aquifer flow $(10.7 \mathrm{~m})$, thickness of the unsaturated zone $(20 \mathrm{~m})$, density of the saturated and unsaturated zone soils $\left(1.5 \mathrm{~g} / \mathrm{cm}^{3}\right)$, saturation ratio exponential parameter of the unsaturated and saturated zones (11.4), hydraulic gradient of the saturated zone (0.0035), total porosity of the unsaturated and saturated zones $(0.42)$, effective porosity of the unsaturated and saturated zones $(0.06)$, water table drop rate $(0.001 \mathrm{~m} / \mathrm{y})$, well pump intake depth ( $10 \mathrm{~m}$ below the water table), and well pumping rate $\left(250 \mathrm{~m}^{3} / \mathrm{y}\right)$, were all estimated in the 1994 report of Pinellas waste sent to Laidlaw (M. H. Chew \& Associates 1994). The same values were used in this assessment. The porosities of the unsaturated and saturated zones are from the default values given in the RESRAD manual for clay (Yu et al. 1993, Table E.7, p. 210). Similarly, the saturation exponential parameter used in RESRAD, which affects the saturation rate of the medium, is based on a clay (Yu, et al. 1993, Table E.2, 
p. 200). The well drop rate and the well pumping rate are both from the RESRAD default values. For more details on these parameters, see Yu et al. (1993).

In order to calculate the dose, additional exposure factors are needed. The exposed individual is conservatively assumed to consume $100 \%$ of his water $(2 \mathrm{~L} / \mathrm{d}$ for $365 \mathrm{~d} / \mathrm{y}=730$ $L / y$ ) from the contaminated well. EPA uses this value as a conservative estimate of a persons intake of water (EPA 1989). The tritium ingestion dose conversion factor used in this analysis is $64 \mathrm{rem} / \mathrm{Ci}$ (EPA 1988, ICRP 1979).

The annual dose represented over time is shown in Fig. 3.1. The maximum public dose of $5.7 \times 10^{-1} \mathrm{mrem} / \mathrm{y}$ occurs after about 2 years. The dose initially increases with time as tritium leaches into the groundwater. However, after approximately 2 years, the dose begins to decrease with time. The dose estimate sensitivity of each parameter and their implications are described in Sect. 3.3.2.

\subsection{Sensitivity Analysis}

\subsubsection{Worker exposure scenarios}

For the worker scenarios (water evaporation and diffusion models), several parameters were modified to represent an upper bound or another reasonable value of that parameter. Each parameter was modified independently to determine the difference in dose estimates from the base case. The base case includes the doses from the four worker exposure scenarios calculated above in Sect. 3.1. The results from the base case are as follows:

$$
\begin{array}{ll}
\text { sampling } & 7.2 \times 10^{-6} \mathrm{mrem} / \mathrm{y} \\
\text { stabilization } & 2.4 \times 10^{-6} \mathrm{mrem} / \mathrm{y} \\
\text { acute burial } & 9.9 \times 10^{-7} \mathrm{mrem} / \mathrm{y} \\
\text { chronic burial } & 1.5 \times 10^{-6} \mathrm{mrem} / \mathrm{y}
\end{array}
$$

Although there are many conservative assumptions in the base case dose analysis, this sensitivity analysis modifies various parameter values to determine the impact on the dose analysis. In general, this sensitivity analysis takes values that would lead to higher doses. However, in some cases, this analysis varies parameter values based on some reasonable upper or lower bound, which may result in lower doses.

The following parameters were evaluated in this sensitivity analysis: the ambient temperature and associated vapor pressure of water, the wind speed, the exposure times for sampling, stabilization, and burial operations, the inhalation rate, the mixing height, the landfill cell quadrant dimensions, the waste porosity, and the cover depth. Table 3.1 lists the parameter values used in the base case and in the sensitivity analysis, and Table 3.2 presents 




Fig. 3.1. Public Dose from Ingestion of Tritium-contaminated Drinking Water. 
Table 3.1 Parameter values for worker exposure sensitivity analysis

\begin{tabular}{lcc}
\hline Parameter & \multicolumn{2}{c}{ Parameter value } \\
\hline & Base case & Sensitivity analysis \\
\cline { 2 - 3 } temperature $\left({ }^{\circ} \mathrm{C}\right)$ & 38 & 24 \\
vapor pressure $(\mathrm{mm} \mathrm{Hg})$ & 33 & 25 \\
wind speed $(\mathrm{m} / \mathrm{s})$ & 0.5 & 3 \\
exposure time & & \\
$\quad$ sampling $(\mathrm{s})$ & 600 & 900 \\
$\quad$ stabilization $(\mathrm{s})$ & 1800 & 2700 \\
$\quad$ burial-acute $(\mathrm{s})$ & 300 & 600 \\
$\quad$ burial-chronic (s/y) & $3.6 \times 10^{6}$ & $7.2 \times 10^{6}$ \\
inhalation rate (m $/ \mathrm{s})$ & $4.17 \times 10^{-4}$ & $8.33 \times 10^{-4}$ \\
mixing height (m) & 3 & 0.3 \\
burial quadrant dimensions (m $\mathrm{x}$ m) & $15.2 \times 15.2$ & $23 \times 23$ \\
waste effective porosity (dimensionless) & 0.2 & 0.4 \\
cover depth (m) & 1.8 & 2.4 \\
\hline
\end{tabular}

Table 3.2 Sensitivity analysis for worker exposure calculations

\begin{tabular}{|c|c|c|c|c|}
\hline \multirow[t]{2}{*}{ Varied parameter } & \multicolumn{4}{|c|}{ Dose (mrem/y) } \\
\hline & Sampling & Stabilization & Burial-Acute & Burial-Chronic \\
\hline & \multicolumn{4}{|c|}{ Base Case Doses } \\
\hline & $7.2 \times 10^{-6}$ & $2.4 \times 10^{-6}$ & $9.9 \times 10^{-7}$ & $1.5 \times 10^{-6}$ \\
\hline & \multicolumn{4}{|c|}{ Sensitivity Analysis Doses } \\
\hline $\begin{array}{l}\text { temperature and } \\
\text { vapor pressure }\end{array}$ & $4.7 \times 10^{-6}$ & $1.6 \times 10^{-6}$ & $6.4 \times 10^{-7}$ & NA \\
\hline wind speed & $2.0 \times 10^{-6}$ & $1.6 \times 10^{-6}$ & $6.7 \times 10^{-7}$ & $2.5 \times 10^{-7}$ \\
\hline $\begin{array}{l}\text { exposure time } \\
\text { sampling } \\
\text { stabilization } \\
\text { burial-acute } \\
\text { burial-chronic }\end{array}$ & $\begin{array}{l}7.2 \times 10^{-6} \\
\text { NA } \\
\text { NA } \\
\text { NA }\end{array}$ & $\begin{array}{l}\text { NA } \\
3.6 \times 10^{-6} \\
\text { NA } \\
\text { NA }\end{array}$ & $\begin{array}{l}\text { NA } \\
\text { NA } \\
2.0 \times 10^{-6} \\
\text { NA }\end{array}$ & $\begin{array}{l}\text { NA } \\
\text { NA } \\
\text { NA } \\
3.0 \times 10^{-6}\end{array}$ \\
\hline inhalation rate & $1.4 \times 10^{-5}$ & $4.8 \times 10^{-6}$ & $2.0 \times 10^{-6}$ & $3.0 \times 10^{-6}$ \\
\hline mixing height & NA & $2.4 \times 10^{-5}$ & $9.9 \times 10^{-6}$ & $1.5 \times 10^{-5}$ \\
\hline burial quadrant dimensions & NA & NA & $1.5 \times 10^{-6}$ & $2.2 \times 10^{-6}$ \\
\hline waste effective porosity & NA & NA & NA & $3.0 \times 10^{-6}$ \\
\hline cover depth & NA & NA & NA & $1.1 \times 10^{-6}$ \\
\hline
\end{tabular}

NA=parameter not applicable to specific exposure scenario. 
the results of the sensitivity analysis. The following information provides details on the sensitivity analysis for each parameter.

Ambient temperature and associated vapor pressure of water $\left(T_{\text {vap }}\right.$ and $P_{\text {vap }}, E q$. 3-2). The dose analysis conservatively assumed that operations were conducted during the hottest month of the year. However, operations are expected to occur in April or May. The sensitivity analysis assumed a lower-bound temperature, based on the mean daily maximum temperature for April of $24^{\circ} \mathrm{C}$. The corresponding vapor pressure of water at this temperature is $25 \mathrm{~mm} \mathrm{Hg}$. With these inputs for the vapor temperature and vapor pressure in Eq. 3-2, the doses to the sampler, stabilization worker, and the landfill worker (acute scenario) are each reduced by a factor of only about 1.5 .

Wind speed ( $u$, Eqs. 3-6, 3-12, and 3-13). In the base case, the wind speed was also very conservatively estimated to be at calm conditions $(0.5 \mathrm{~m} / \mathrm{s})$. If the average wind speed for Columbia, South Carolina were used (i.e., $3 \mathrm{~m} / \mathrm{s}$ ), the doses would be between about 2 to 6 times less than the base case, depending on the exposure scenario.

Exposure times for sampling, stabilization, and burial (T, Eq. 3-1; $\left.f_{e s}, E q .3-18\right)$. The exposure times estimated for each scenario in the base case are as follows: 10 minutes for sampling, 30 minutes for stabilization, 5 minutes for waste burial operations and 4 hours per day for 250 working days of the year $\left(3.6 \times 10^{6} \mathrm{~s} / \mathrm{y}\right)$ for chronic landfill exposure. The sensitivity analysis assumed sampling took 15 minutes, stabilization took 45 minutes, burial took 10 minutes, and the landfill worker spent 8 hours a day for 250 days $\left(7.2 \times 10^{6} \mathrm{~s} / \mathrm{y}\right)$ near the buried waste. Because exposure time is directly proportional to the dose, the factor difference in the time is the same as the factor difference in the dose. For example, a doubling of exposure time would double the dose. The changes in dose for each scenario are shown in Table 3.2.

Inhalation rate (IR, Eqs. 3-1 and 3-18). The worker exposure scenarios assumed an inhalation rate associated with someone executing light exercise $\left(4.17 \times 10^{-4} \mathrm{~m} / \mathrm{s}\right.$; ICRP 1994). Assuming the worker was breathing heavier, the dose would increase. The sensitivity analysis assumed a worker inhalation rate from heavy exercise of $8.33 \times 10^{-4}$ $\mathrm{m} / \mathrm{s}$ (ICRP 1994). This is a doubling of inhalation rate, which corresponds to a doubling of dose for each scenario. 
Mixing height $\left(A_{\imath}, A_{s}, E q .3-12\right)$. The mixing height was estimated to be $3(10 \mathrm{ft}) \mathrm{m}$ for the stabilization and burial scenarios. If this were reduced by an order of magnitude, to $0.3 \mathrm{~m}$ ( $1 \mathrm{ft}$ ), the doses would change by the same factor. The doses would be between $1.0 \times 10^{-5}$ and $1.5 \times 10^{-5}$, which are still very low (see discussion of results, Sect. 4).

Landfill cell quadrant dimensions $\left(A_{b}, A_{s}, E q .3-12\right)$. The actual dimensions of the quadrant where the Pinellas waste will be placed is unknown. The majority of quadrants have dimensions of $15.2 \mathrm{~m} \times 15.2 \mathrm{~m}$ (50 ft $\times 50 \mathrm{ft}$ ). If the dimensions were increased to $23 \mathrm{~m} \mathrm{x} 23 \mathrm{~m}$ ( $75 \mathrm{ft} \times 75 \mathrm{ft}$ ), the dose would increase proportionally (i.e., increase by a factor of 1.5 ).

Waste porosity (P, Eq. 3-17). The effective porosity of the waste was assumed to be 0.2 , which is associated with a silt-like material. If the effective porosity were 0.4 (i.e., a reasonable upper-bound value that may be associated with a sand-or graveltype material), the dose to the landfill worker would double.

Cover depth (L, Eq. 3-16). The cover depth at Laidlaw ranges from $1.8 \mathrm{~m}(6 \mathrm{ft})$ to 2.4 $\mathrm{m}(8 \mathrm{ft})$. The base case analysis used a cover of $1.8 \mathrm{~m}$. If it were increased to $2.4 \mathrm{~m}$ $(8 \mathrm{ft}$ ), the dose to the landfill worker (chronic scenario) would be reduced by a factor of 1.3 .

In every case, the doses did not change more than an order of magnitude. Since the doses in the base case are at such low levels (i.e., in the range of millionths of millirem), none of the possible changes in input parameters would have a significant effect on the outcome of this analysis (see discussion of results, Sect. 4).

\subsubsection{Public exposure scenario}

Sensitivity analyses were also conducted on the conservative RESRAD code calculations, which resulted in a peak public dose of $5.7 \times 10^{-1} \mathrm{mrem} / \mathrm{y}$ at approximately 2 years after burial. The RESRAD code has the capability to alter parameter values by any percent above and below the base parameter value to determine the impact of that parameter on the outcome. When possible, parameter values were changed by an order of magnitude $(900 \%)$. In some cases, there is a maximum or minimum value that does not allow the parameter to be changed by $900 \%$. Therefore, the code modifies the percent to the maximum possible for that parameter. In other cases, information is available about the parameter that 
provides upper and/or lower bounds of the parameter value. In these cases, a more realistic percent change is used in the sensitivity analysis. As in the worker exposure scenario sensitivity analysis, each parameter was modified independently, keeping all other parameters constant for the base case.

The only parameters that were not changed by a percent using the RESRAD sensitivity capabilities were the area and thickness of the contaminated zone. Because these two parameters are not independent, varying each one separately is not accurate. Instead, the area was modified by $150 \%$ (as in the worker sensitivity analysis) and the resulting thickness for that area was calculated based on a constant waste volume of $172 \mathrm{~m}^{3}$.

Table 3.3 lists the 31 parameters that were evaluated, their sensitivity, percent variation in parameter value estimate, and, if applicable, the factor increase in dose from the base case. The parameters are labeled as either "insensitive" (no change in dose with a change in parameter value), "slightly sensitive" (less than an order of magnitude change in dose with a change in parameter value), or "sensitive" (one order of magnitude change in dose with a change in parameter value). Twelve of the parameters were completely insensitive to the calculated dose. Eleven parameter values, which are listed as slightly sensitive, resulted in maximum doses when the base case value was used. Therefore, although the doses were slightly sensitive to changes in the parameter value, the base case dose was always the most conservative. Six other parameters that were slightly sensitive caused the base case doses to increase by less than a factor of 2.5. The remaining two parameters, density of the contaminated zone and the water ingestion rate, were the most sensitive. These parameters are linearly related to the dose and an increase in the parameter value by an order of magnitude results in an a proportional increase in the dose:

Density of the contaminated zone. The density of the contaminated zone was estimated at $1.15 \mathrm{~g} / \mathrm{cm}^{3}$ in the 1994 report of similar waste, and the same density is assumed here. Increasing the density by $900 \%$ would result in a dose of $5.7 \mathrm{mrem} / \mathrm{y}$ at about 2 years. However, the density is more likely to vary by maybe $50 \%$, which would cause only a factor increase in the potentially maximum dose of $1.5\left(8.6 \times 10^{-1} \mathrm{mrem} / \mathrm{y}\right)$.

Water ingestion rate. The ingestion rate equivalent to $2 \mathrm{~L} / \mathrm{d}$, every day of the year (i.e., $730 \mathrm{~L} / \mathrm{y}$ ) is assumed in the analysis. This conservatively assumes that the maximally exposed individual consumes $2 \mathrm{~L} / \mathrm{d}$ of water all from the contaminated well. The default value in RESRAD is only $510 \mathrm{~L} / \mathrm{y}$. The $2 \mathrm{~L} / \mathrm{d}$ is the value recommended by EPA in the 1989 Exposure Factors Handbook (EPA 1989), which states that it is "an overestimate for most people and is used to represent a long-term average consumption rate." Therefore, this is assumed to be adequately conservative to compensate for any sensitivity in the model. Furthermore, altering the water ingestion rate value by an order of magnitude (equivalent to $20 \mathrm{~L} / \mathrm{d}$ ) would far exceed any actual consumption rate. Finally, even if it were increased by an order of magnitude, an 
Table 3.3 Summary of RESRAD sensitivity analysis for public exposure calculation

\begin{tabular}{|c|c|c|c|}
\hline Parameter & Sensitivity $^{a}$ & $\begin{array}{c}\text { Percent } \\
\text { variation in } \\
\text { parameter value }\end{array}$ & $\begin{array}{c}\text { Approximate factor } \\
\text { increase in base case } \\
\text { dose }^{b}\end{array}$ \\
\hline area and thickness of contaminated zone & slightly sensitive & $150 \%^{c}$ & $\mathrm{NA}^{d}$ \\
\hline length parallel to aquifer flow & slightly sensitive & $900 \%$ & $\mathrm{NA}^{d}$ \\
\hline cover depth & insensitive & $900 \%$ & NA \\
\hline cover depth erosion rate & insensitive & $900 \%$ & NA \\
\hline density of contaminated zone & sensitive & $900 \%$ & 10 \\
\hline contaminated zone erosion rate & insensitive & $900 \%$ & NA \\
\hline contaminated zone total porosity & slightly sensitive & $150 \%$ & 2.5 \\
\hline contaminated zone effective porosity & insensitive & $400 \%$ & NA \\
\hline contaminated zone hydraulic conductivity & slightly sensitive & $900 \%$ & 1.1 \\
\hline $\begin{array}{l}\text { contaminated zone saturation ratio } \\
\text { exponential parameter }\end{array}$ & slightly sensitive & $183 \%$ & 1.2 \\
\hline humidity in air & insensitive & $900 \%$ & NA \\
\hline evapotranspiration coefficient & slightly sensitive & $35 \%$ & 1.1 , peaks at earlier time \\
\hline precipitation & slightly sensitive & $687 \%$ & $\mathrm{NA}^{d}$ \\
\hline runoff coefficient & slightly sensitive & $50 \%$ & 1.1 , peaks at earlier time \\
\hline watershed area for nearby stream or pond & insensitive & $900 \%$ & NA \\
\hline density of saturated zone & insensitive & $900 \%$ & NA \\
\hline saturated zone total porosity & insensitive & $138 \%$ & NA \\
\hline saturated zone effective porosity & slightly sensitive & $900 \%$ & 1.1 , peaks at earlier time \\
\hline saturated zone hydraulic conductivity & slightly sensitive & $900 \%$ & $\mathrm{NA}^{d}$ \\
\hline saturated zone hydraulic gradient & slightly sensitive & $900 \%$ & $\mathrm{NA}^{d}$ \\
\hline $\begin{array}{l}\text { saturated zone saturation ratio exponential } \\
\text { parameter }\end{array}$ & insensitive & $32 \%$ & NA \\
\hline water table drop rate & insensitive & $900 \%$ & NA \\
\hline well pump intake depth & slightly sensitive & $900 \%$ & $\mathrm{NA}^{d}$ \\
\hline well pumping rate & slightly sensitive & $900 \%$ & $\mathrm{NA}^{d}$ \\
\hline
\end{tabular}


Table 3.3 (cont.)

\begin{tabular}{lccc}
\hline Parameter & Sensitivity & $\begin{array}{c}\text { Percent } \\
\text { variation in } \\
\text { parameter value }\end{array}$ & $\begin{array}{c}\text { Approximate factor } \\
\text { increase in base case } \\
\text { dose }\end{array}$ \\
\hline unsaturated zone thickness & slightly sensitive & $900 \%$ & $\mathrm{NA}^{d}$ \\
unsaturated zone soil density & insensitive & $900 \%$ & $\mathrm{NA}$ \\
unsaturated zone total porosity & insensitive & $138 \%$ & $\mathrm{NA}$ \\
unsaturated zone effective porosity & slightly sensitive & $900 \%$ & $\mathrm{NA}^{d}$ \\
unsaturated zone hydraulic conductivity & slightly sensitive & $900 \%$ & $\mathrm{NA}^{d}$ \\
unsaturated zone saturation ratio & slightly sensitive & $32 \%$ & $\mathrm{NA}^{d}$ \\
exponential parameter & & & 10 \\
water ingestion rate & sensitive & $900 \%$ & 10 \\
\hline
\end{tabular}

${ }^{a}$ Parameters that result in a no change in the dose value are labeled "insensitive", those that result in a change in value of less than one order of magnitude are labeled "slightly sensitive", and those that change by an order of magnitude are labeled "sensitive".

${ }^{b}$ The base case results in a dose of $5.7 \times 10^{-1} \mathrm{mrem} / \mathrm{y}$ to the member of the public at approximately 2 years after burial of the waste. "NA" refers to parameters that do not result in an increase in dose after being altered in the sensitivity analysis.

${ }^{c}$ Since the area and thickness of the contaminated zone are not independent, these two parameter values were not evaluated separately. The surface area was modified by $150 \%$ (as in the worker sensitivity analysis) and the resulting thickness was calculated based on a constant waste volume of $172 \mathrm{~m}^{3}$. These two parameters were used in the RESRAD code to evaluate the sensitivity of these two parameters together.

${ }^{d}$ By increasing or decreasing the parameter value, the dose never exceeds the base case.

increase by an order of magnitude in the dose would still result in a very low dose to a member of the public (see Sect. 4) Because the base case analysis was so conservative, changes to many of the parameter values would not increase the dose. The only two parameters that were sensitive have less uncertainty in their base case values than some of the other values and would not likely vary by an order of magnitude as assumed in this sensitivity analysis. Therefore, the conclusions from the sensitivity analysis are that the public dose analysis is very conservative and would not be greatly affected by reasonable fluctuations in parameter values. 


\section{DISCUSSION OF RESULTS}

\subsection{Summary of Results}

The results of this upper-bound dose assessment reveal low to extremely low doses (Table 4.1). The conservative assumptions made throughout the analyses lead to overestimates of dose. Table 4.2 lists some of the major assumptions, the exposure scenario affected by those assumptions, and whether the assumptions are conservative. For assumptions that may not necessarily be conservative, the results of the sensitivity analysis showed no major impact on doses.

Table 4.1 Summary of radiological doses

\begin{tabular}{|c|c|c|c|}
\hline Exposure scenario & Dose $(\text { mrem } / y)^{a}$ & $\begin{array}{l}\text { fraction of natural } \\
\text { background }^{b}\end{array}$ & $\begin{array}{c}\text { fraction of regulatory } \\
\text { limit }^{c}\end{array}$ \\
\hline Waste sampling & $7.2 \times 10^{-6}$ & $2.4 \times 10^{-8}$ & $1.4 \times 10^{-9}$ \\
\hline Waste stabilization & $2.4 \times 10^{-6}$ & $8.0 \times 10^{-9}$ & $4.8 \times 10^{-10}$ \\
\hline \multicolumn{4}{|l|}{ Waste burial } \\
\hline acute & $9.9 \times 10^{-7}$ & $3.3 \times 10^{-9}$ & $2.0 \times 10^{-10}$ \\
\hline chronic & $1.5 \times 10^{-6}$ & $5.0 \times 10^{-9}$ & $3.0 \times 10^{-10}$ \\
\hline Public exposure ${ }^{d}$ & $5.7 \times 10^{-1}$ & $1.9 \times 10^{-3}$ & $5.7 \times 10^{-3}$ \\
\hline \multicolumn{4}{|c|}{$\begin{array}{l}{ }^{a} \text { Waste sampling, waste stabilization, and acute burial doses are from short-term exposure scenarios that } \\
\text { occur within one year. Because the doses are so low, no acute radiation effects are anticipated. Therefore, the most } \\
\text { reasonable comparison is to annual background and annual occupational dose levels. The chronic waste burial and } \\
\text { public exposure scenarios are from longer-term exposures that are also compared to annual background and annual } \\
\text { occupational doses. } \\
{ }^{b} \text { Annual average individual natural background level is } 300 \mathrm{mrem} \text {. } \\
{ }^{c} \text { Occupational limit }=5000 \mathrm{mrem} / \mathrm{y} ; \text { public limit }=100 \mathrm{mrem} / \mathrm{y} \text {. } \\
{ }^{d} \text { Peak annual exposure occurs about } 2 \text { years after placement of waste. }\end{array}$} \\
\hline
\end{tabular}

\subsection{Comparison to Background and Regulatory Limits}

The doses calculated in this analysis are compared to background levels and existing regulatory limits. The average background dose from all sources of radiation to a U. S. individual is about $360 \mathrm{mrem} / \mathrm{y}$. The contribution from natural sources is about $300 \mathrm{mrem} / \mathrm{y}$ (NCRP 1987). The Nuclear Regulatory Commission (NRC) and DOE annual occupational dose limits are both 5,000 mrem (NRC 1995, DOE 1989). The NRC dose limit for protection of the public from all sources and all pathways combined is $100 \mathrm{mrem} / \mathrm{y}$ (NRC 1995). 
Table 4.2 Major assumptions

\begin{tabular}{|c|c|c|c|}
\hline Assumption & $\begin{array}{l}\text { Affected } \\
\text { scenario }^{a}\end{array}$ & Comment $^{b}$ & \\
\hline $\begin{array}{l}\text { The inhalation/percutaneous dose conversion factor accounts for } \\
\text { direct inhalation as well as absorption of tritiated water vapor } \\
\text { through the skin. }\end{array}$ & $1,2,3,4$ & $\begin{array}{l}\text { Conservative - the use of personal protective equipment would reduce } \\
\text { the surface area of exposed skin and thus the amount of tritium } \\
\text { absorbed through the skin. }\end{array}$ & \\
\hline The inhalation rate is for workers conducting light exercise. & $1,2,3,4$ & See sensitivity analysis (Sect. 3.3.1). & \\
\hline The evaporation rate of tritiated water is based on a water spill. & $1,2,3$ & $\begin{array}{l}\text { Conservative - a water spill would likely result in greater evaporation } \\
\text { of vapor into the air than water in a sludge or grout. }\end{array}$ & \\
\hline $\begin{array}{l}\text { In the sampling exposure analysis, all the water vapor in the } \\
\text { headspace comes from the waste and all the tritium is in the } \\
\text { sludge water. }\end{array}$ & 1 & $\begin{array}{l}\text { Conservative - not all the water vapor in the headspace would } \\
\text { necessarily be from the waste. }\end{array}$ & \\
\hline $\begin{array}{l}\text { Operations are conducted in July (therefore, the maximum } \\
\text { average temperature and thus water vapor pressure are used). }\end{array}$ & $1,2,3$ & $\begin{array}{l}\text { Conservative - the higher temperature and vapor pressure result in } \\
\text { greater evaporation and thus greater tritium concentration in the air. } \\
\text { See sensitivity analysis (Sect. 3.3.1). }\end{array}$ & $\hat{N}$ \\
\hline $\begin{array}{l}\text { The mixing depth of the contaminated exposure zone is the } \\
\text { distance traveled in one second of the contaminated air moving at } \\
\text { the exit velocity out of the vacuum box during sampling }(0.20 \mathrm{~m}) \text {. }\end{array}$ & 1 & $\begin{array}{l}\text { Conservative - for times beyond one second, the velocity of the outside } \\
\text { air would have moved the tritiated vapor beyond the breathing zone of } \\
\text { the sampling worker. This is a conservative assumption since the } \\
\text { individual taking the sample is not likely to get closer than } 0.6 \mathrm{~m} \text { from } \\
\text { the opening. }\end{array}$ & \\
\hline The wind speed is under calm conditions $(0.5 \mathrm{~m} / \mathrm{s})$. & $1,2,3,4$ & $\begin{array}{l}\text { Conservative - a calm wind speed results in lower dilution of tritium in } \\
\text { the air and therefore a air concentration and greater dose to the worker. } \\
\text { See sensitivity analysis (Sect. 3.3.1). }\end{array}$ & \\
\hline Sampling time is 10 minutes. & 1 & See sensitivity analysis (Sect. 3.3.1). & \\
\hline
\end{tabular}


Table 4.2 (cont.)

\begin{tabular}{|c|c|c|}
\hline Assumption & $\begin{array}{l}\text { Affected } \\
\text { scenario }^{a}\end{array}$ & Comment $t^{b}$ \\
\hline The porosity of the waste is 0.2 (effective porosity of silt). & 4 & See sensitivity analysis (Sect. 3.3.1). \\
\hline $\begin{array}{l}\text { The receptor ingests } 100 \% \text { of his water that is taken from a well } \\
\text { at the downgradient edge of the contaminated area. }\end{array}$ & 5 & $\begin{array}{l}\text { Conservative - a person is likely to ingest water from other sources. } \\
\text { See sensitivity analysis (Sect. 3.3.2). }\end{array}$ \\
\hline $\begin{array}{l}\text { The engineered barriers designed to minimize migration of tritium } \\
\text { off-site do not work. }\end{array}$ & 5 & $\begin{array}{l}\text { Conservative - greater leaching of tritium would occur, resulting in a } \\
\text { greater dose if the barrier properties are ignored. }\end{array}$ \\
\hline The distribution coefficient of the underlying geology $\left(\mathrm{K}_{d}\right)$ is zero & 5 & $\begin{array}{l}\text { Conservative - this assumption means there is no retardation of tritium } \\
\text { in the soils as it is transported to the hypothetical well. This would } \\
\text { result in a maximum concentration and dose. }\end{array}$ \\
\hline $\begin{array}{l}\text { The hydraulic conductivity of the saturated zone is about } 1.05 \mathrm{x} \\
10^{-3} \mathrm{~cm} / \mathrm{s}(330 \mathrm{~m} / \mathrm{y})\end{array}$ & 5 & $\begin{array}{l}\text { Conservative - the value of the hydraulic conductivity of the saturated } \\
\text { zone was chosen because it results in the maximum dose. See } \\
\text { sensitivity analysis (Sect. 3.3.2). }\end{array}$ \\
\hline
\end{tabular}

a This table refers to the following exposure scenarios:

1 = sampling

$2=$ stabilization

3 = acute burial

$4=$ chronic burial

$5=$ public

${ }^{b}$ Conservative assumptions are those that result in a reasonable upper-bound dose estimate. 
The worker doses from sampling, stabilization, and waste burial, and the public dose from ingestion of tritium are presented in Table 4.1. All the estimated doses are far below the natural background levels and the applicable regulatory limits. The percents of the natural background and of the regulatory limits for each scenario are also presented in Table 4.1. The worker doses from waste operations are 40 to 300 million times less than radiation doses from natural sources and 0.7 to 5 billion times less than the regulatory limit. The total public dose is about 530 times less than natural background and 180 times less than the NRC public limit. Therefore, despite the conservative assumptions about the potentially maximally exposed individuals, the doses are well below the regulatory limits, as well as being only a very small fraction of the average U.S. background levels.

The sensitivity analysis done on the worker and public exposure calculations (Sect. 3.3) show that the doses would be within an order of magnitude of those calculated. Further, it is unlikely that the public dose estimate would ever increase by that much due to the very conservative assumptions used in the analysis. Because the doses are so far below any level of concern, shown in Table 4.1, and the input parameter values are relatively insensitive to changes, the conclusion is drawn that the doses are very low and not of regulatory concern.

\subsection{Health Effects}

The health effect associated with low-dose exposures to radiation is cancer. The risk of excess cancer fatalities has been quantified based on atomic bomb exposure data in which large doses of radiation were received. To determine cancer risks at low doses, a common assumption is that exposure to a carcinogen and the development of cancer follow a linear, nothreshold dose-response relationship. The International Commission on Radiological Protection (ICRP) used the atomic bomb exposure data to estimate excess cancer risks per unit dose due to chronic, low dose exposures. These conversion factors for workers and the public are $4 \times 10^{-4}$ and $5 \times 10^{-4}$ excess risk/rem, respectively. Despite the linear, no-threshold assumption, the ICRP cautions against using the cancer risk conversion factors for such low doses as those presented in this analysis. Therefore, although this assessment does not specifically quantify the excess cancer risk, the risk would be below (and far below for the worker scenarios) $1 \times 10^{-6}$, or any risk level of concern. 


\section{REFERENCES}

Baver, L. D. 1956. Soil Physics, 3rd Ed. John Wiley \& Sons, Inc., New York. In M. H. \& Chew Associates 1994.

DOC (U. S. Department of Commerce) 1995. Statistical Abstract of the United States 1995, 115th Edition, Washington, DC, September.

DOE (U. S. Department of Energy) 1989, Department of Energy Order 5480.11, "Radiation Protection for Occupational Workers."

EPA (U. S. Environmental Protection Agency) 1989. Exposure Factors Handbook. Office of Health and Environmental Assessment, Environmental Protection Agency, EPA/600/889/043. Washington, DC, July.

EPA (U. S. Environmental Protection Agency) 1988. Limiting Values of Radionuclide In Intake and Air Concentration and Dose Conversion Factors for Inhalation, Submersion, and Ingestion. Federal Guidance Report No. 11. EPA-520/1-88-020, Office of Radiation Programs, Washington, DC, September.

EPA (U. S. Environmental Protection Agency) 1987. Technical Guidance for Hazardous Analysis, Emergency Planning for Extremely Hazardous Substances, U. S.

Environmental Protection Agency, Federal Emergency Management Agency, and U.S. Department of Transportation, Washington, DC.

ICRP (International Commission on Radiological Protection) 1994. "Human Respiratory Tract Model for Radiological Protection," Annals of the ICRP, ICRP Publication 66, Pergamon Press, NY.

ICRP (International Commission on Radiological Protection) 1979. "Limits of Intakes of Radionuclides by Workers," Annals of the ICRP, ICRP Publication 30, Pergamon Press, NY.

Kirkham, D. and W. L. Powers 1972. Advanced Soil Physics, Robert E. Krieger Publishing Company, Malabar, FL.

Laidlaw Environmental Services of South Carolina, Inc., no date. Laidlaw Environmental Services Informational Audit Package, Pinewood Secure Landfill, Pinewood, South Carolina (received from Todd Blake, Laidlaw Environmental Services of South Carolina, Inc., March 11, 1996, estimated publication date, December 1995).

Lide, D. R. (ed.) 1993. Handbook of Chemistry and Physics, 74th Edition, 1993-1994. CRC Press Boca Raton, Florida.

Lombardi, D. A. and M. L. Socolof 1996. "An Assessment of Radionuclide Emissions Associated with Potential Mixed-Low Level Waste Disposal Facilities at Fifteen DOE Sites," 96-TP58.02, Proceedings of the Air and Waste Management Association, June, 1996, Nashville, Tenn., in press. 
M. H. Chew \& Associates, Inc. 1994. Radiological Dose Assessment of Department of Energy Pinellas Plant Waste sent to Laidlaw Environmental Services, Inc., Pinewood, SC. U. S. Department of Energy, Office of Environmental Restoration and Waste Management. June.

NCRP (National Council on Radiation Protection and Measurements) 1987. "Exposure of the Population in the United States and Canada from Natural Background Radiation," National Council on Radiation Protection and Measurements, NCRP Report No. 94, Bethesda, MD.

NRC (U. S. Nuclear Regulatory Commission) 1995. "Standards for Protection Against Radiation," 10 Code of Federal Regulations, Part 20, Subparts C and D, U.S. Regulatory Commission, Washington, DC.

Strock, C. and R. L. Koral 1965. Handbook of Air Conditioning and Ventilating, 2 nd Ed. Industrial Press, New York. In M. H. Chew \& Associates 1994.

Yu, C., A. J. Zielen, J. J. Cheng, Y. C. Yuan, L. G. Jones, D. J. LePoire, Y. Y. Want, C. O. Loureiro, E. Gnanapragasam, E. Faillance, A. Wallo III, W. A. Williams, and H. Peterson 1993. Manual for Implementing Residual Radioactive Material Guidelines Using RESRAD, Version 5.05 (ANL/EAD/LD-2, Working Draft for comment, September 1993) in M. H Chew \& Associates 1994. 
APPENDIX A

RESRAD VERSION 5.60 INPUT PARAMETERS AND DOSE SUMMARY 
A.1 BURIAL WORKER CHRONIC EXPOSURE SCENARIO 
RESRAD, Version $5.60 \quad T^{*}$ Limit $=0.5$ year

Sumary : Laidlaw occupational scenario (chronic)
03/19/96 16:31 Page 2

File: LAIDOCC.DAT

Dose Conversion Factor (and Related) Parameter Sumary

File: LAIDOCC.BIN

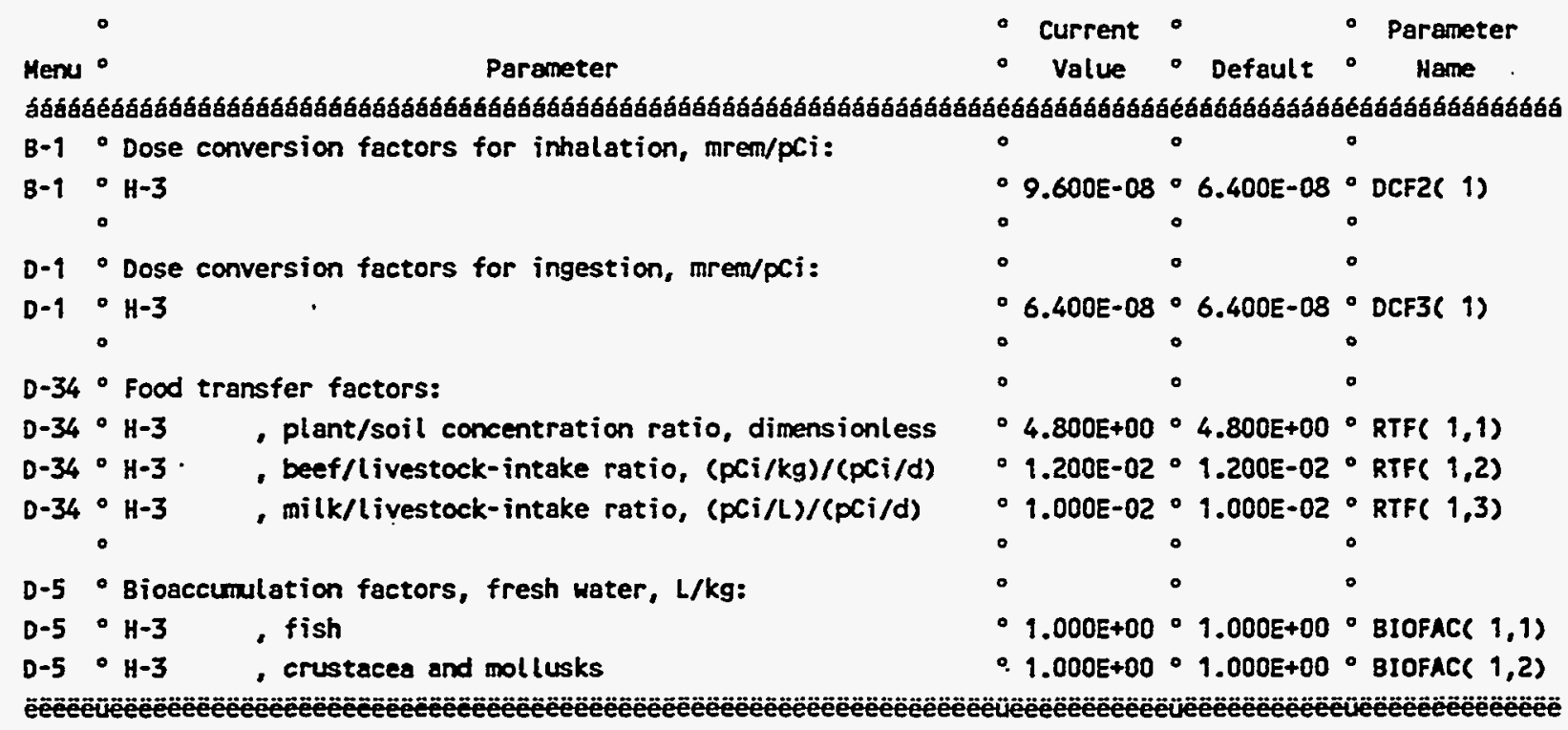


RESRAD, Version $5.60 \quad T^{\prime \prime}$ Limit $=0.5$ year

Sumary : Laidlau occupational scenario (chronic)
03/19/96 16:31 Page 3

File: LAIOOCC.OAT

Site-Specific Parameter Sumary




RESRAD, Version $5.60 \quad T^{*}$ Limit $=0.5$ year

summary : Laidlau occupational scenario (chronic)
03/19/96 16:31 Page 4

File: LAIDOCC.DAT

Site-Specific Parameter Sumary (continued)

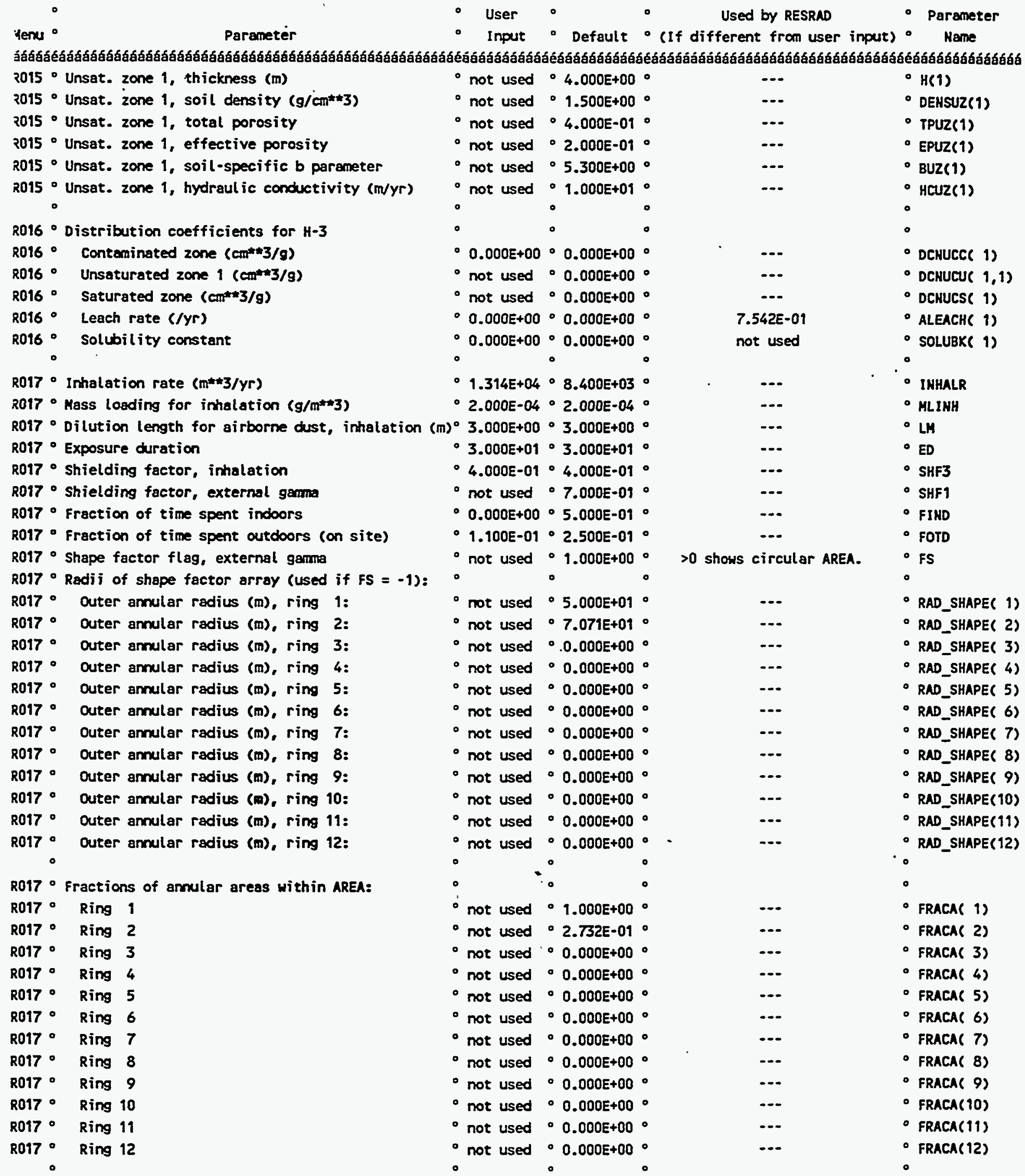






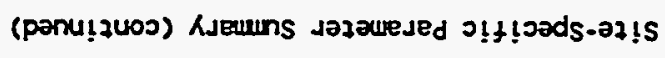

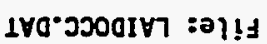

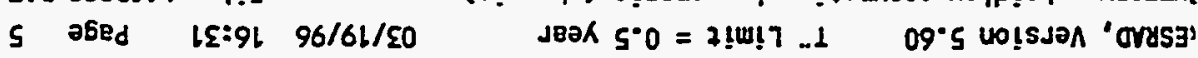


SESRAD, Version $5.60 \quad T^{-}$Limit $=0.5$ year

Sumary = Laidlaw occupational scenario (chronic)
03/19/96 16:31 Page 6

File: LAIDOCC.DAT

Site-Specific Parameter Sumary (continued)

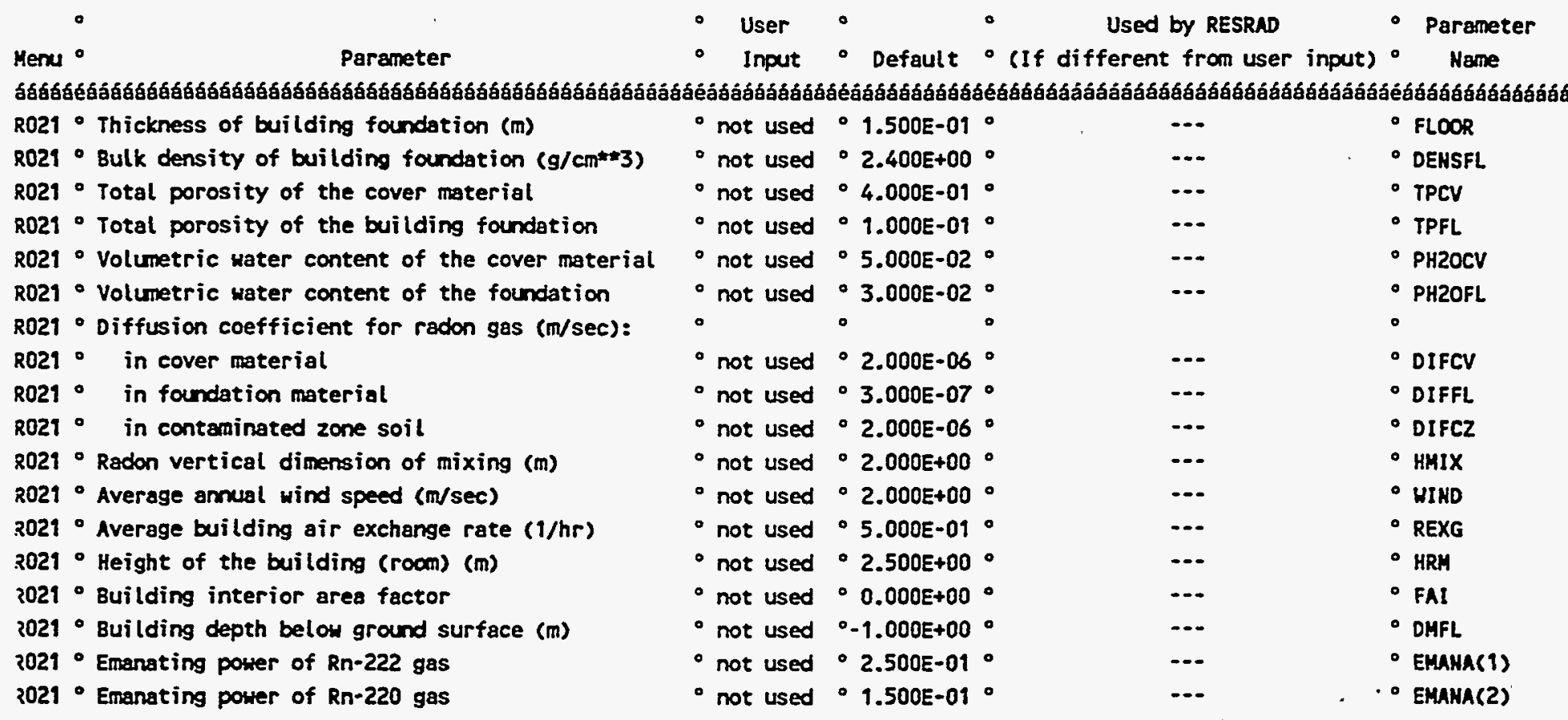

海

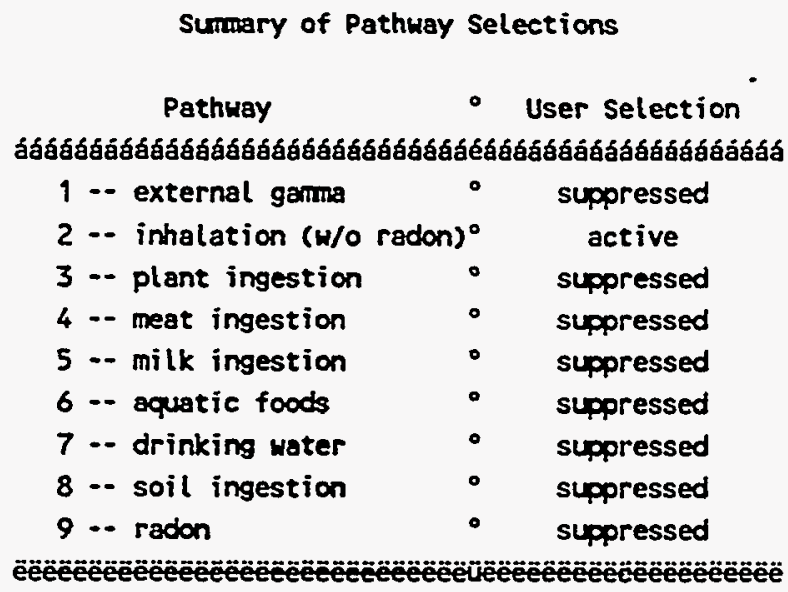




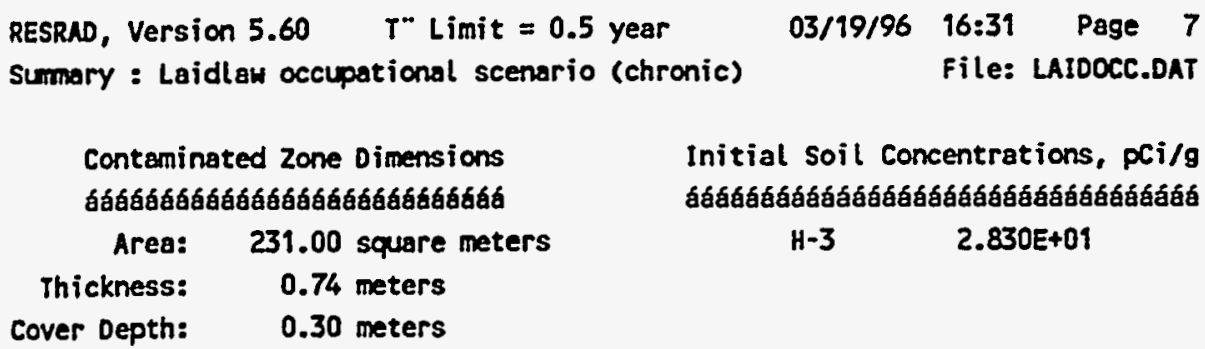

Contaminated Zone Dimensions

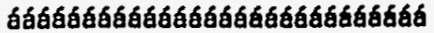
Area: 231.00 square meters

Thickness: $\quad 0.74$ meters Cover Depth: $\quad 0.30$ meters

Initial Soil Concentrations, $p C i / g$

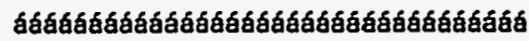

$$
\mathrm{H}-3 \quad 2.830 \mathrm{E}+\mathrm{OI}
$$

Total Dose TOOSE(t), mrem/yr

Basic Radiation Dose Limit $=30 \mathrm{mrem} / \mathrm{yr}$

Total Mixture Sum $M(t)=$ Fraction of Basic Dose Limit Received at Time $(t)$

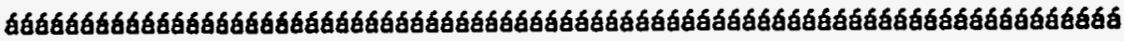

$\begin{array}{rllllllll}t \text { (years): } & 0.000 E+00 & 1.000 E+00 & 3.000 E+00 & 1.000 E+01 & 3.000 E+01 & 1.000 E+02 & 3.000 E+02 & 1.000 E+03 \\ \text { TDOSE(t): } & 0.000 E+00 & 8.670 E-06 & 4.856 E-06 & 2.898 E-08 & 2.567 E-17 & 0.000 E+00 & 0.000 E+00 & 0.000 E+00 \\ M(t): & 0.000 E+00 & 2.890 E-07 & 1.619 E-07 & 9.659 E-10 & 8.556 E-19 & 0.000 E+00 & 0.000 E+00 & 0.000 E+00\end{array}$

Maximum TDOSE(t): $8.819 E-06 \mathrm{mrem} / \mathrm{yr}$ at $t=1.209 \mathrm{p} 0.001$ years

Total Dose Contributions TDOSE(i,p,t) for Individual Radionuclides (i) and Pathways ( $p$ ) As mrem/yr and Fraction of Total Dose At $t=1.209$ years

Water Independent Pathways (Inhalation excludes radion)

\begin{tabular}{|c|c|c|c|c|c|c|c|}
\hline & ond & tion & Radon & Plant & Heat & Milk & Soil \\
\hline & 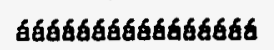 & 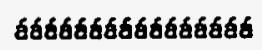 & áááááááááááááá & áááááá & áááááááááááááá & 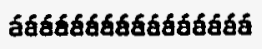 & Gáááááááá \\
\hline 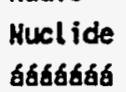 & áá & 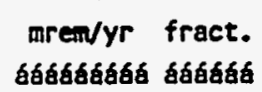 & $\begin{array}{l}\text { yr fract. } \\
\text { áá ásáááá }\end{array}$ & $\begin{array}{c}\text { mren/yr fra } \\
\text { áááááááá áá }\end{array}$ & $\begin{array}{l}y r \\
\text { ýd } \\
\text { íd }\end{array}$ & $\begin{array}{c}\text { mrem/yr } \\
\text { áááááááb́ }\end{array}$ & $\begin{array}{l}\mathrm{mr} \\
\text { ááá }\end{array}$ \\
\hline & $+\infty$ & c & 300 & 30 & 0 & $+\infty 00$ & 00 \\
\hline & & & & & & & \\
\hline & $.000 E+00 \quad 0.0000$ & $.819 E-06 \quad 1.0000$ & $0.000 \varepsilon+00 \quad 0.0000$ & $.000 E+00 \quad 0.0000$ & $0.000 E+00 \quad 0.0000$ & $3.000 E+00 \quad 0.0000$ & $0.000 E+000$ \\
\hline
\end{tabular}

Total Dose Contributions TDOSE $(i, p, t)$ for Individual Radionuclides (i) and Pathways ( $p$ ) As mrem/yr and Fraction of Total Dose At $t=1.209$ years

Water Dependent Pathways

\begin{tabular}{|c|c|c|c|c|c|c|c|}
\hline & ater & Fish & adon & Plant & Meat & Milk & \\
\hline & 66 & G6tá6t & Gáágé & 66 & 6́ & 6 & \\
\hline & 白 & 168 & íá & $\begin{array}{ll}r & 1 \\
\text { iáá } & \text { á }\end{array}$ & éáá & 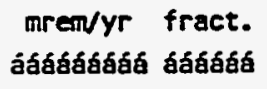 & ỹr frá \\
\hline & $000 E+000$. & $00 \quad 0.0000$ & OOOE+00 0 & $+\infty 0$ & $+\infty 00$. & $=+000$. & -06 \\
\hline & & & & & & & \\
\hline & $E+000.0$ & $10 E+00 \quad 0.0000$ & $.000 E+00 \quad 0.0000$ & $.000 E+00 \quad 0.0000$ & $.000 E+00 \quad 0.0000$ & $0.000 E+000.0000$ & $8.819 E-061.0000$ \\
\hline
\end{tabular}

\#Sum of all water independent and dependent pathways. 
A.2 PUBLIC DOSE EXPOSURE SCENARIO 
RESRAD, Version $5.60 \quad T^{*}$ Limit $=0.5$ year Sumary : Laidlen public dose
03/27/96 16:35 Page 2

File: LAIDLAW.DAT

Dose Conversion Factor (and Related) Parameter Sumary

file: DOSFAC.BIN

\begin{tabular}{|c|c|c|c|c|}
\hline Merus & Parameter & $\begin{array}{l}\text { - Current } \\
\text { - Value }\end{array}$ & - Default & $\begin{array}{l}\text { - Parameter } \\
\text { - Mane }\end{array}$ \\
\hline iáá &  & & & \\
\hline $8-1$ & - Dose conversion factors for inhalation, mrem/pci: & $\bullet$ & - & - \\
\hline B-1 & - $\mathrm{H}-3$ & $\begin{array}{l}-6.400 E-08 \\
.\end{array}$ & $\begin{array}{l}\cdot 6.400 \mathrm{E}-08 \\
.\end{array}$ & $\begin{array}{l}-\operatorname{DCF2}(1) \\
-\end{array}$ \\
\hline $0-1$ & - Dose conversion factors for ingestion, mrem/pci: & $\circ$ & $\circ$ & - \\
\hline$D-1$ & ${ }_{0}^{\circ} \mathrm{H}-3$ & $\begin{array}{l}\text { - } 6.400 \mathrm{E}-08 \\
.\end{array}$ & $\begin{array}{l}0.400 E-08 \\
.\end{array}$ & $\begin{array}{l}-\operatorname{DCF3}(1) \\
-\end{array}$ \\
\hline $0-34$ & - Food transfer factors: & $\circ$ & - & $\bullet$ \\
\hline D-34 & - plant/soil concentration ratio, dimensionless & - $4.800 E+00$ & - $4.800 E+00$ & $\cdot \operatorname{RTF}(1,1)$ \\
\hline D-34 & , beef/livestock-intake ratio, (pCi/kg)/(pCi/d) & $.1 .200 E-02$ & - $1.200 E-02$ & - RTF( 1,2) \\
\hline$D-34$ & , milk/livestock-intake ratio, $(p \mathrm{pi} / \mathrm{L}) /(\mathrm{pCi} / \mathrm{d})$ & $\therefore 1.000 E-02$ & - $1.000 E-02$ & - $\operatorname{RTF}(1,3)$ \\
\hline D-5 & - Bioaccumulation factors, fresh water, L/kg: & $\circ$ & & $\circ$ \\
\hline $0-5$ & ${ }^{\circ} \mathrm{H}-3$, fish & - 1.000E+00 & $=1.000 E+00$ & - Bloface 1,1$)$ \\
\hline $0-5$ & , crustacea and mollusks & - $1.000 E+00$ & - $9.000 E+00$ & - bloface 1,2$)$ \\
\hline
\end{tabular}

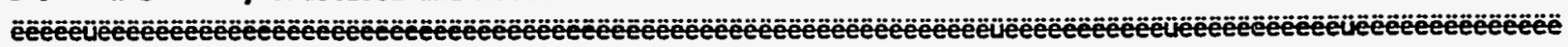


RESRAD, Version $5.60 \quad T$ Limit $=0.5$ year

sumary : Laidlan public dose
03/27/96 16:35 Page 4

File: LAIDLAW.DAT

Site-Specific Parameter Sumary (continued)

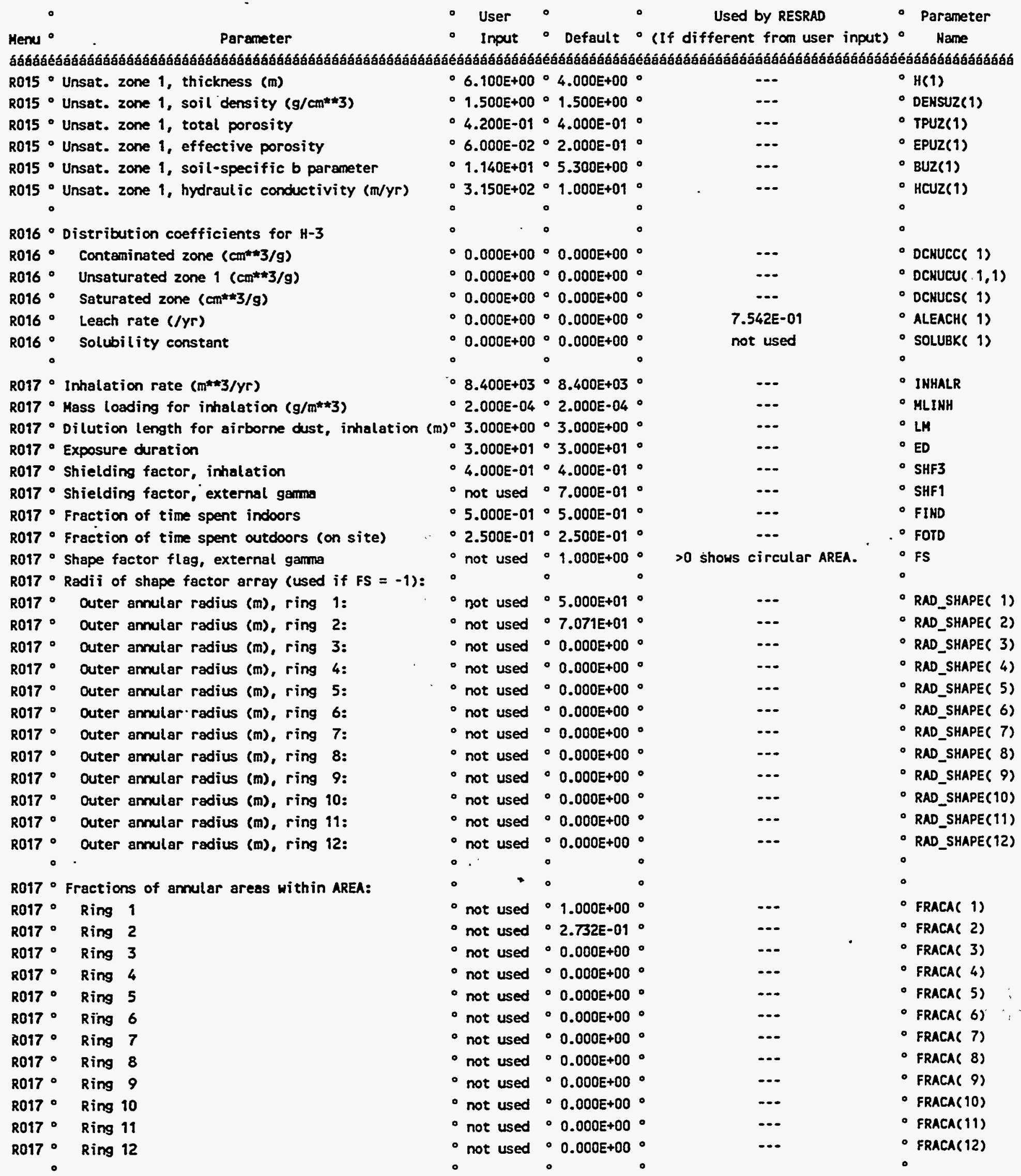




\begin{tabular}{|c|c|c|}
\hline possajddhs & 。 & uoped \\
\hline possajddins & 。 & $40 ! 28064 ! 1 ! 05$ \\
\hline ว^! 208 & 。 & دә78n Bu!xu!Jp \\
\hline әА! & 。 & spoo! 2! 7 enbe \\
\hline DA! 120 & - & uo!3506u! \\
\hline әヘ!7כอ & - & 40!7506u! 7000 \\
\hline әА! & - & Uo!zsasu! zuejd \\
\hline әヘ!ุวอ & ofuoped & O/M) UO!fEןELU! \\
\hline possadddns & 。 & cume6 jeusəzxo \\
\hline
\end{tabular}

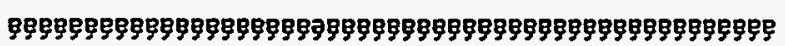

- vo!zzojas jasn o Kenyzed



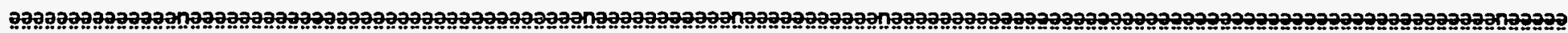

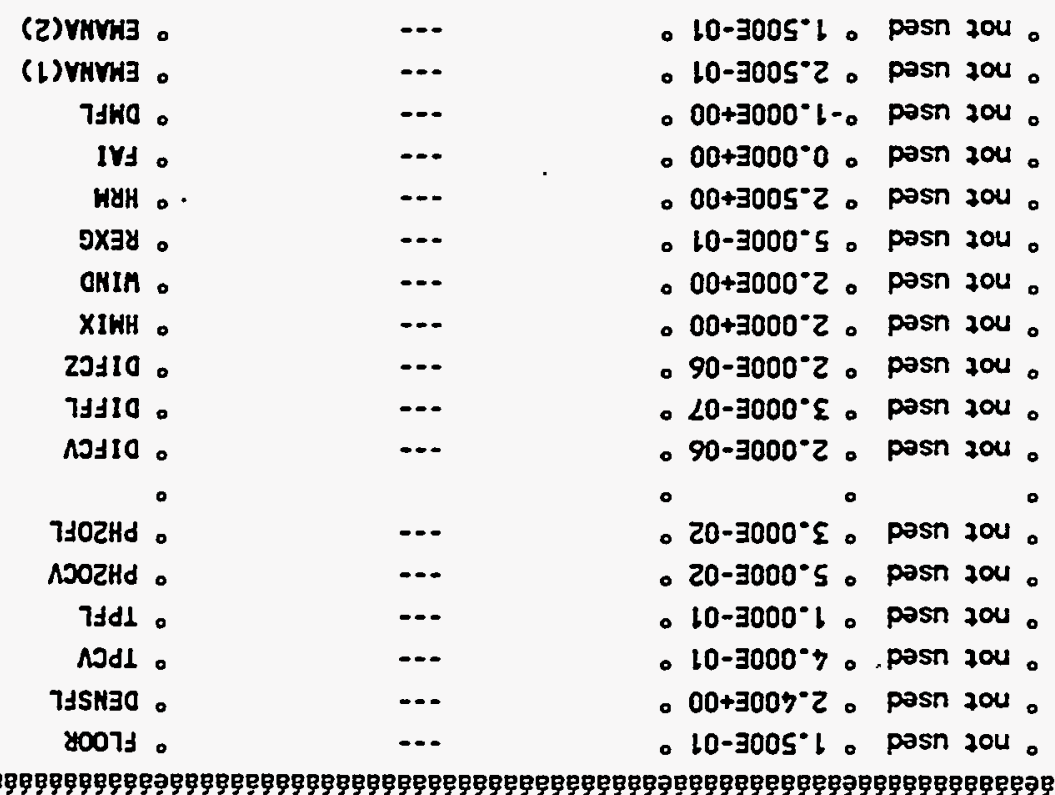

SB6 0ZC-uy to jimod Butzeuruy - L204

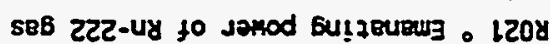

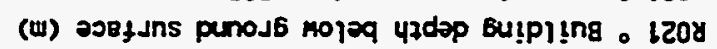

s0758t eaje so!jsazu! Qutpling 。 lzoy

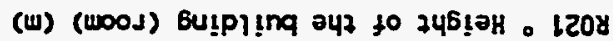

(

(20s/ur) paads pu!n jenuub asejany o Lzoy

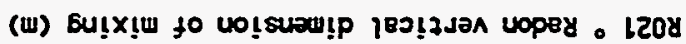

llos zw0z pazeutwezuos u! o l208

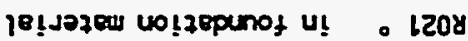

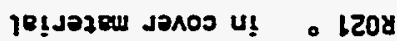

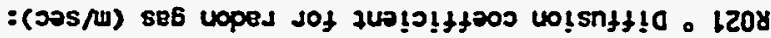

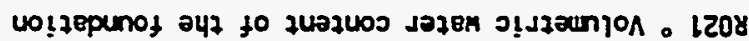

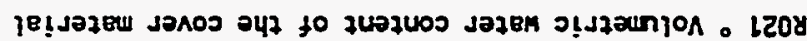

vo!zepunot Eu!pling 247 to 17 !sosod j8301 - 1208

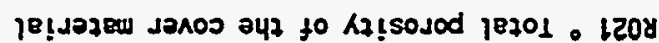

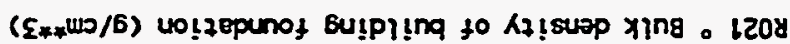

(w) vo!z8punos bu!pl!ng to ssouxp!41 。 1208

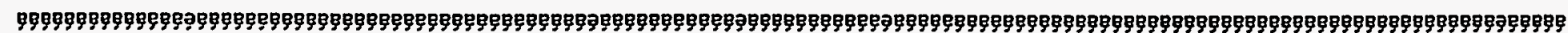

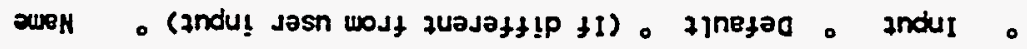

jozauresed o aryszy kq pasn o dasn 0

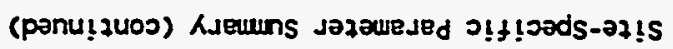

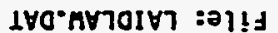

9 a6ed cE:9l $96 / 2 Z / \Sigma O$

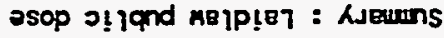
Jeak $5^{\circ} 0=7 ! w ! 7.1$ 09.5 vi!sjan "Ordsay 
RESRAD, Version $5.60 \quad T^{-}$Limit $=0.5$ year Sumary : Laidlan public dose

Contaminated Zone Dimensions

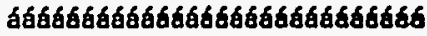

Area: 231.00 square meters

Thickness: $\quad 0.74$ maters

Cover Depth: $\quad 1.80$ meters

\section{3/27/96 16:35 Page 7}

File: LAIDLAH.DAT

Initial Soil Concentrations, pCi/g

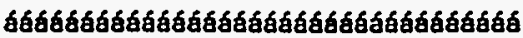

$\mathrm{H}-3 \quad 2.830 \mathrm{E}+01$

Total Dose TDOSE(t), mrem/yr

Basic Radiation Dose Limit $=30 \mathrm{mrem} / \mathrm{yr}$

Total Mixture Sum $M(t)=$ Fraction of Basic Dose Limit Received at Time $(t)$

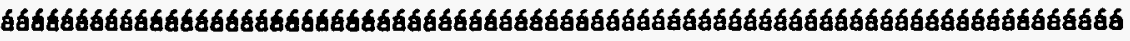

$\begin{array}{rllllllll}t \text { (years): } & 0.000 E+00 & 1.000 E+00 & 3.000 E+00 & 1.000 E+01 & 3.000 E+01 & 1.000 E+02 & 3.000 E+02 & 1.000 E+03 \\ \text { TDOSE }(t): & 0.000 E+00 & 0.000 E+00 & 2.987 E-01 & 1.028 E-03 & 9.428 E-11 & 0.000 E+00 & 0.000 E+00 & 0.000 E+00 \\ M(t): & 0.000 E+00 & 0.000 E+00 & 9.95 B E-03 & 3.428 E-05 & 3.143 E-12 & 0.000 E+00 & 0.000 E+00 & 0.000 E+00\end{array}$

Maximum TDOSE(t): $5.661 E-01 \mathrm{mren} / \mathrm{yr}$ at $t=2.211 p 0.002$ years

Total Dose Contributions TOOSE $(i, p, t)$ for Individual Radionuclides (i) and Pathways ( $p$ )

As mren/yr and Fraction of Total Dose At $t=2.211$ years

Water Independent Pathways (Inhalation excludes radon)

\begin{tabular}{|c|c|c|c|c|c|c|c|}
\hline & & & & & Meat & & \\
\hline & 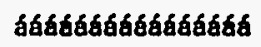 & 0 & Gáá & & f́áá & ááááá & \\
\hline & ir & yr f & $6 \dot{6}$ & Sía & Ir & yr & $\begin{array}{l}\text { yr } \\
\text { ásá }\end{array}$ \\
\hline & & 0 & 00 & & 00 & +00 & \\
\hline & & & & & & & \\
\hline & & 10 & $=+000$. & $.000 E+000$ & $E+00 \mathrm{C}$ & $0.000 E+000$ & $0.000 E+00$ \\
\hline
\end{tabular}

Total Dose Contributions TDOSE$(i, p, t)$ for Individual Radionuclides (i) and Pathways $(p)$.

As mrem/yr and Fraction of Total Dose At $t=2.211$ years

Water Dependent Pathways

\begin{tabular}{|c|c|c|c|c|c|c|c|}
\hline & $H$ & h & & & Meat & & \\
\hline & & & & & & & \\
\hline & 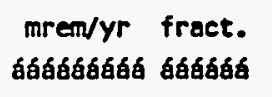 & 6 & 16 & b & a & ás á & áá \\
\hline & & & & & & 40 & 11 \\
\hline & & & & & & & \\
\hline - & 010.9987 & $691 E-060.0000$ & $.000 E+00 \quad 0.0000$ & $.000 E+000.0000$ & $.612 E-04 \quad 0.0003$ & $.675 E-04 \quad 0.0010$ & $.661 E-011.0000$ \\
\hline
\end{tabular}

"Sum of all water independent and dependent pathways. 


\section{INTERNAL DISTRIBUTION}

1-10. M. L. Socolof

11-12. K. E. Bowman

13. G. E. Courville

14. Tim Ensminger

15. D. W. Lee

16. D. A. Lombardi

17. C. I. Moser

18. R. M. Reed
19. R. B. Shelton

20. G. P. Zimmerman

21. ORNL Patent Office

22. Central Research Library

23. Document Reference Section

24-25. Laboratory Records

26. Laboratory Records-RC

\section{EXTERNAL DISTRIBUTION}

27. Dr. Thomas E. Drabek, Professor, Department of Sociology, University of Denver, Denver, CO 80208-0209

28. Dr. Stephen G. Hildebrand, Director, Environmental Sciences Division, Oak Ridge National Laboratory, P.O. Box 2008, Oak Ridge, Tennessee 37831-6037

29. Mr. George F. Sowers, P.E., Senior Vice President, Law Companies Group, Inc., 114 Townpark Drive, Suite 250, Kennesaw, GA 30144-5599

30. Dr. C. Michael Walton, Ernest H. Cockrell Centennial Chair in Engineering and Chairman, Department of Civil Engineering, University of Texas at Austin, Austin, Texas $78712-1076$

31. ORNL Site Manager, U.S. Department of Energy, Oak Ridge National Laboratory, P.O. Box 2008, Oak Ridge, Tennessee 37831-6269

32-33. OSTI, U.S. Department of Energy, P.O. Box 62, Oak Ridge, Tennessee 37831 